Annales Geophysicae (2003) 21: 281-297 (C) European Geosciences Union 2003

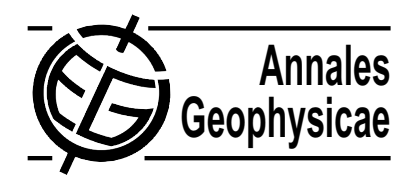

\title{
Simulation and analysis of the mesoscale circulation in the northwestern Mediterranean Sea
}

\author{
V. Echevin ${ }^{1}$, M. Crépon ${ }^{1}$, and L. Mortier ${ }^{2}$ \\ ${ }^{1}$ Laboratoire d'Océanographie Dynamique et de Climatologie, Paris, France \\ ${ }^{2}$ Ecole Nationale Supérieure des Techniques Avancées, Paris, France
}

Received: 6 July 2001 - Revised: 23 September 2002 - Accepted: 6 October 2002

\begin{abstract}
The large-scale and mesoscale circulation of the northwestern Mediterranean Sea are simulated with an eddyresolving primitive-equation regional model $(\mathrm{RM})$ of $1 / 16^{\circ}$ resolution embedded in a general circulation model (GM) of the Mediterranean Sea of $1 / 8^{\circ}$ resolution. The RM is forced by a monthly climatology of heat fluxes, precipitation and wind stress. The GM, which uses the same atmospheric forcing, provides initial and boundary conditions for the RM.

Analysis of the RM results shows that several realistic features of the large-scale and mesoscale circulation are evident in this region. The mean cyclonic circulation is in good agreement with observations. Mesoscale variability is intense along the coasts of Sardinia and Corsica, in the Gulf of Lions and in the Catalan Sea. The length scales of the Northern Current meanders along the Provence coast and in the Gulf of Lions' shelf are in good agreement with observations. Winter Intermediate Water is formed along most of the north-coast shelves, between the Gulf of Genoa and Cape Creus. Advection of this water by the mean cyclonic circulation generates a complex eddy field in the Catalan Sea. Intense anticyclonic eddies are generated northeast of the Balearic Islands. These results are in good agreement with mesoscale activity inferred from satellite altimetric data. This work demonstrates the feasibility of a downscaling system composed of a general-circulation, a regional and a coastal model, which is one of the goals of the Mediterranean Forecasting System Pilot Project.
\end{abstract}

Key words. Oceanography: physical (currents; eddies and mesoscale processes; general circulation)

\section{Introduction}

The aim of the Mediterranean Forecasting System (Pinardi et al., 2001a) is to forecast the circulation and characteristics of the Mediterranean water masses on a global scale $(\sim 10-50 \mathrm{~km})$, to a coastal scale $(\sim 2 \mathrm{~km})$. To satisfy this

Correspondence to: V. Echevin

(echevin@lodyc.jussieu.fr) goal, several ocean-circulation models with different spatial scales have been implemented. The Modular Ocean Model (MOM; hereafter referred to as the Global Model, GM), a rigid-lid primitive-equation model derived from the GFDL model, has been used by the ISAO-CNR team to simulate the circulation and water-mass characteristics in the Mediterranean basin (Demirov and Pinardi, 2002). At the regional scale $(4-5 \mathrm{~km})$, a circulation model of the Liguro-Provenal basin has been developed. The rigid-lid primitive-equation OPA model (Madec et al., 1998) has been implemented in the area north of $39.9^{\circ} \mathrm{N}$ (the southern boundary of the model intersects the northern extremity of Minorca, the easternmost Balearic Island), and between $0^{\circ} \mathrm{E}$ (the Catalonian coast) and $10.5^{\circ} \mathrm{E}$ (the Italian coast). This regional model (hereafter referred to as RM), initialised and forced at its open boundaries by outputs of the GM, was used to simulate the circulation in the Ligurian Sea, the Gulf of Lions, and the north Catalan Sea. The RM will provide initial and open boundary conditions for shelf models of the Gulf of Lions and the Catalan Sea (Pinardi et al., 2001b).

The operational forecasting of the circulation at global, regional and coastal scale in the Mediterranean can only be achieved if (a) the models are forced by realistic atmospheric fluxes, (b) the model results are validated with the available observations, and (c) data-assimilation methods are implemented to increase the model predictability. The first step to achieving these goals is to run the models in a climatological mode (i.e. taking into account climatological forcing), and validate the output with Mediterranean Sea climatological data. A GM simulation using a climatological forcing has been performed by the ISAO-CNR group. The results of this experiment were used to initialise and force the RM at its open boundaries. In the present work we focus on the results of the regional model.

The present paper is structured as follows: Sect. 2 describes the climatological atmospheric forcing used in the simulations; Sect. 3, the GM and RM configuration; Sect. 4 presents the results of the RM simulation; Sect. 5, the conclusions. 


\section{Atmospheric forcing}

The same climatological forcing was used both for the GM and the RM. The wind stress and heat (solar, latent, sensible) fluxes were built from a $1^{\circ}$ by $1^{\circ}$ monthly climatology of the European Centre for Medium-term Weather Forecasting (ECMWF) model Re-analysis over the period 1979-1993 (Korres, 2002). Latent and sensible heat fluxes were calculated using the ECMWF re-analysis atmospheric parameters following Kondo (1975). The longwave heat flux was calculated according to Bignami et al. (1995). For more details on the computations of the surface fluxes, the reader is refered to the Korres (2002) paper. The net annual heat budget is positive, $+17.9 \mathrm{~W} / \mathrm{m}^{2}$, the annual evaporative budget is $1.0 \mathrm{~m} /$ year. This net heating is in contradiction with the heat loss estimates from hydrographic measurements, which lay in the range of $-7 \pm 3 \mathrm{~W} / \mathrm{m}^{2}$ (Bethoux, 1979) and $-5.2 \pm 1.3 \mathrm{~W} / \mathrm{m}^{2}$ (Macdonald et al., 1994). The biased heat budget may induce a temperature drift in the long term. However, the heat-flux formulation includes an additional restoring term to the climatological MODB sea-surface temperature, with a restoring coefficient set to $25 \mathrm{~W} / \mathrm{m}^{2} /{ }^{\circ} \mathrm{C}$. After eight years of GM climatological integration, the annual heat budget is equal to $-4.9 \mathrm{~W} / \mathrm{m}^{2}$ (Korres, 2002). The same heat fluxes formulation was used in the RM, to remain consistent with the GM. Since a relatively short integration of 3 years was performed with the RM, the drift is negligible (less than $0.01{ }^{\circ} \mathrm{C}$ in 3 years). Evaporation fluxes are computed from the latent-heat flux, and precipitation is specified by the LEGATES climatology (Legates, 1987).

\section{Mediterranean global model (GM) and regional model (RM)}

The GM used is the MOM which was adapted to the Mediterranean Sea. The model grid has 31 z-levels in the vertical, as in Korres et al. (2000), and a horizontal resolution of $1 / 8^{\circ} \cdot 1 / 8^{\circ}$. At this spatial resolution, the model is eddypermitting. Horizontal turbulent mixing is biharmonic with tracer coefficients equal to $1.5 \cdot 10^{10} \mathrm{~m}^{4} / \mathrm{s}$ and momentum coefficients equal to $2 \cdot 10^{10} \mathrm{~m}^{4} / \mathrm{s}$. Vertical turbulent processes are parameterised by a constant turbulent-diffusion coefficient set equal to $0.3 \cdot 10^{-4} \mathrm{~m}^{2} / \mathrm{s}$, a viscosity coefficient equal to $1.5 \cdot 10^{-4} \mathrm{~m}^{2} / \mathrm{s}$. A standard convective adjustment scheme is applied when static instability appears in the water column.

A six-year-long simulation was performed with the GM. Monthly mean GM ouputs of the sixth year of simulation were used for the initialisation and open-boundary forcing of the RM.

The primitive equation OPA7 model, which has been used to study dynamical processes in the Mediterranean Sea (Madec et al., 1991; Herbaut et al., 1996, 1997), was implemented in a regional configuration with lateral open boundaries (Deleville, 1997). The model is eddy-resolving and has a horizontal resolution of $1 / 16^{\circ}$ in longitude, $1 / 16^{\circ} \cdot \cos (\phi)$ in latitude (where $\phi$ is the latitude), which ensures an exact isotropy of the horizontal grid. The resolution varies between $5.3 \mathrm{~km}$ at $40^{\circ} \mathrm{N}$ and $4.9 \mathrm{~km}$ at $44.5^{\circ} \mathrm{N}$. The vertical grid comprises $37 z$-levels whose resolution varies between $6 \mathrm{~m}$ near the surface and $200 \mathrm{~m}$ at $2800 \mathrm{~m}$ depth. The horizontal diffusion is biharmonic, with tracer and momentum coefficients equal to $5 \cdot 10^{8} \mathrm{~m}^{4} / \mathrm{s}$. Vertical diffusivity of the tracers and velocity are calculated with a mixed-layer model based on a turbulent kinetic energy scheme (Blanke and Delecluse, 1993). A no-slip boundary condition is used at the coasts and at the bottom.

The bottom topography of the model is that of the $1 / 16^{\circ}$ by $1 / 16^{\circ} \cdot \cos (\phi)$ Mediterranean model of the French MERCATOR project (Bahurel, 1999). The bottom topography was modified in a band of $\sim 50 \mathrm{~km}$ width north of $39.9^{\circ} \mathrm{N}$, the latitude of the southern open boundary of the RM, and in the Tyrrhenian Sea, in such a way that the bottom topography of the RM matches that of the GM.

At the initial time, tracer and velocity fields from the GM were interpolated on the RM grid. The interpolation scheme is bilinear in the horizontal, linear in the vertical. The scheme does not take into account any dynamical constraint. The interpolation of velocity on the RM grid requires special care: with brute-force interpolation from the GM vertical grid onto the RM one may produce divergent transport fields which are inconsistent with the rigid-lid hypothesis of the OPA7 model. Therefore, the barotropic components of the velocity were modified so that the integrated barotropic transport was nondivergent.

The interpolated temperature, salinity and velocity fields determine the initial state of the RM. After the initialisation, the GM fields are imposed along the southern open boundary of the RM, and in the part of the Tyrrhenian Sea included in the RM domain (between $9^{\circ} \mathrm{E}$ and $10.5^{\circ} \mathrm{E}$, and south of the Corsican channel). In this last region, Newtonian relaxation (with a time scale of 1 week) towards the GM temperature and salinity fields was imposed.

Note that the tracer and velocity data produced by the GM simulation, forced by climatological atmospheric fluxes, are not climatological data, since they contain the large mesoscale eddies. An ensemble mean on each month of a multi-annual GM simulation would be necessary to filter out these eddy structures without smoothing the seasonal cycle. Consequently, some mesoscale eddies are present in the initial state and in the open-boundary forcing of the RM. The former is not a problem, since new eddies are created during a spin-up phase of approximately two months, owing to the adjustment of the initial field to the dynamics and topography of the RM. The latter may induce spurious effects. Consider the case of an eddy which slowly propagates along or across one of the open boundaries of the RM domain during the year. When this open-boundary forcing is used repeatedly to force the RM for several years, a discontinuity in the open-boundary forcing (which is partially smoothed by the temporal interpolation between monthly averages) occurs at the end of the year. This may have an impact on the dynamics near the open boundary, even though we did not estimate it (only one year of GM data was provided). 
Different open-boundary formulations were used for velocity and tracers. The barotropic stream function was specified along the open boundary, as in Stevens and Johnson (1997). The baroclinic velocity was also specified at the open boundary. Temperature and salinity values were specified in the case of inflow into the RM domain, whereas an upstream advection scheme was used in the case of outflow. This allows tracer boundary values to evolve when fluid is advected out of the RM domain. This formulation of the open-boundary conditions was found to be efficient and did not produce artifacts in the circulation. The introduction of an Orlanski-type radiation scheme (Orlanski, 1976) was not necessary.

The Rhone River runoff was introduced into the RM via a constant precipitation flux of $1000 \mathrm{~m}^{3} / \mathrm{s}$ into one RM grid cell located at the river mouth. Seasonal variations in the river flux were not taken into account. An upstream advection scheme for tracers was used in the vicinity of the river mouth. This runoff was introduced differently in the GM: the GM surface salinity was relaxed towards the climatological MED5 surface salinity, in which the Rhone signature is apparent over the whole Gulf of Lions' shelf.

The RM was initialised on 1 January, year I, with the GM temperature, salinity and velocity. Open-boundary values were interpolated linearly in time for each RM model time step. During the first 10 days, a time step of 6.7 min was used, to allow the propagation of short-scale inertia-gravity waves generated by the adjustment of the dynamics to the initial state. During the rest of the simulation period (3 years), the model was run with a time step of $20 \mathrm{~min}$.

\section{Results}

4.1 Adjustment of the RM dynamics during the spin-up phase

During a two-month period following the initialisation (hereafter referred to as the spin-up phase), the density and velocity fields adjust to the RM topography, spatial resolution and dynamics, which are different from those of the GM. The total kinetic energy in the top $100 \mathrm{~m}$ of the water column approximately doubles in the RM during the spin-up phase. Starting from an initial value of $0.5 \mathrm{~m}^{3} / \mathrm{s}^{2}$, which corresponds to the GM initial state interpolated on the RM grid, it reaches $1 \mathrm{~m}^{3} / \mathrm{s}^{2}$ at the end of February. During the rest of the simulation, it oscillates between $0.8 \mathrm{~m}^{3} / \mathrm{s}^{2}$ and $1.4 \mathrm{~m}^{3} / \mathrm{s}^{2}$, showing a clear seasonal cycle with minimum values in summer (Fig. 1a). Note that these energy values are relatively close to those of the GM (Fig. 1b). However, this result is very sensitive to the vertical resolution of the GM grid.

A cyclonic gyre covers the entire basin at the initial time (1 January). At the end of the spin-up phase, several mesoscale eddies have appeared in the RM (Fig. 2). Meandering of the current around the cyclonic gyre has been generated by baroclinic instability which is able to develop in the RM. Cyclonic eddies are generated all around the gyre. The intense
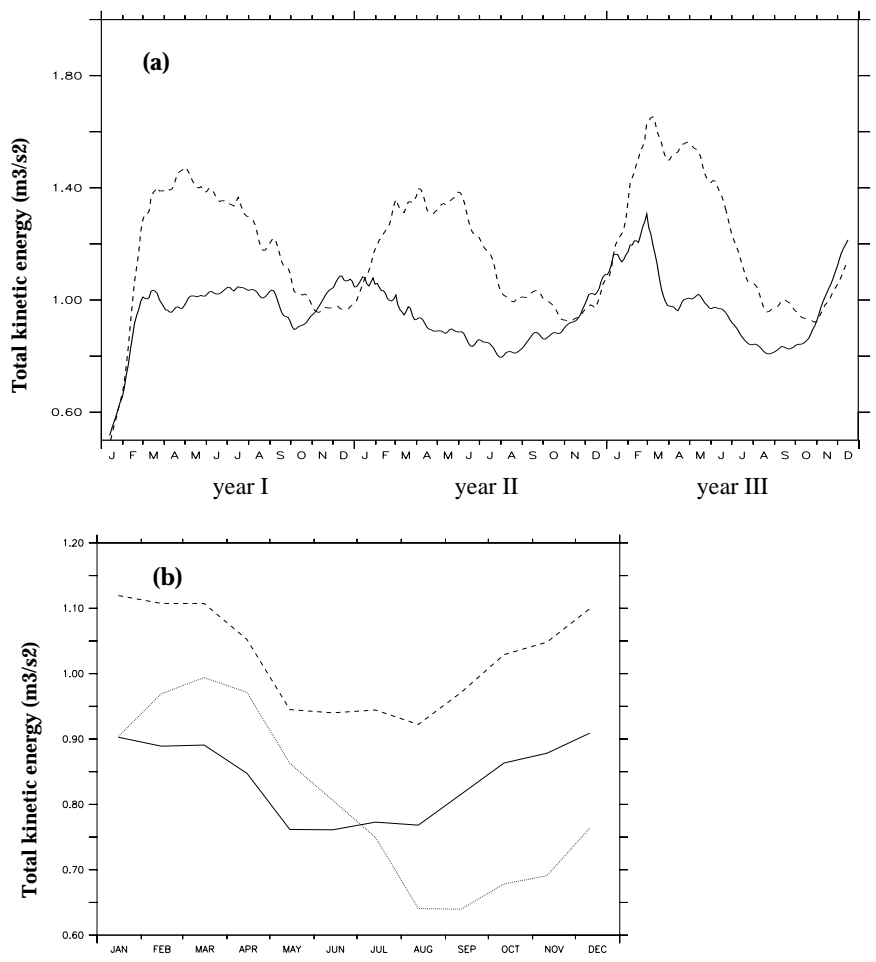

Fig. 1. Temporal evolution of the total kinetic energy vertically integrated, horizontally averaged, and normalized by the mean density $\rho_{0}$. (a) RM model. Full line: integration between 0 and $100 \mathrm{~m}$; dashed line: integration between $100 \mathrm{~m}$ and $500 \mathrm{~m}$. (b) GM model. Full line: integration between 0 and $105 \mathrm{~m}$; dash-dotted line: integration between 0 and $140 \mathrm{~m}$, dashed line: integration between 105 and $500 \mathrm{~m}$.

anticyclonic eddy (denoted A in Figs. 2 and 3) northwest of Sardinia, whose signature is evident in the annual mean barotropic stream function of the GM, is present in the RM (Figs. 2 and 3). A cyclonic eddy has developed in the Gulf of Genoa. At the end of the spin-up phase, the boundary currents in the RM are narrower, as shown by the close-packed isolines in Fig. 2.

In the following subsections, we describe and analyse the large-scale and mesoscale circulation in several regions in the basin. We first briefly describe the GM results and compare them with the RM results, focusing on the large-scale circulation.

\subsection{Large-scale circulation}

\subsubsection{In the GM}

The large-scale cyclonic gyre represented in Fig. 3a is present in the GM during the entire year. The mean annual transport of this gyre is $3 \mathrm{~Sv}$, and three smaller cyclonic gyres with radius of $\sim 75 \mathrm{~km}$ and transport $\sim 0.5-1 \mathrm{~Sv}$ coexist within the large gyre. Between these cyclonic gyres, a small anticyclonic gyre of $\sim 0.5 \mathrm{~Sv}$ is located northeast of Minorca (the land area near $4^{\circ} \mathrm{E} 40^{\circ} \mathrm{N}$ indicated in Fig. 2). This an- 


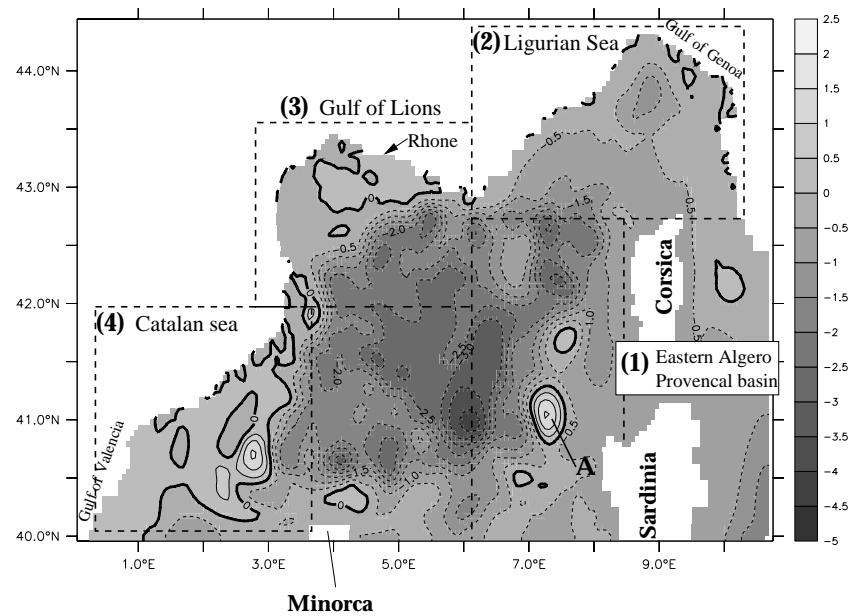

Fig. 2. Barotropic stream function of the RM model on 3 March, year I. Isoline units are in Sverdrups (Sv), at $0.5-\mathrm{Sv}$ intervals. Four sub-regions, (1), (2), (3), (4) are delimited by dashed lines. (A) denotes an anticyclonic eddy.

ticyclone may have been forced by the northwesterly windstress curl at this location, referred to by Millot (1999).

The Sardinian current, which flows northwards along the west coast of Sardinia and Corsica (Millot, 1987), is not trapped near the Sardinian West Coast in the GM. It meanders to the west near $7^{\circ} \mathrm{E} 41.5^{\circ} \mathrm{N}$, owing to the presence of an intense anticyclonic eddy (A in Fig. 3a). A diffuse flow crosses the west Ligurian Sea towards the Provence coast instead of following the Corsican coast, as formerly described (Millot, 1987). There it merges with the eastern Corsican current (hereafter referred to as ECC), which flows from the Tyrrhenian Sea into the Ligurian Sea through the Corsican channel, and along the Ligurian coast.

These two currents form the north current (hereafter referred to as NC), east of $\sim 6^{\circ} \mathrm{E}-7^{\circ} \mathrm{E}$. It flows along the Gulf of Lions' shelf break, impinges on the Catalonian coast, leaving it again south of $41.5^{\circ} \mathrm{N}$ instead of following the coast farther south, as described by Millot (1987) and Font et al. (1995). This current (now named the Balearic current, hereafter BC) veers eastwards north of Minorca. Most of the NC-BC flow ( $\sim 2 \mathrm{~Sv}$ ) recirculates in the basin-scale cyclonic gyre; little of it (less than $0.5 \mathrm{~Sv}$ ) flows southwards between Minorca and the Catalonian coast.

\subsubsection{In the RMM}

Many similar features are evident in the RM annual mean barotropic stream function. The intensity of the large-scale gyre is weaker ( 1.5-2 Sv; Figs. 3b-d) than in the GM (3 Sv; Fig. 3a). The anticyclonic eddy (A) northwest of Sardinia, also present in the GM, is particularly intense during year I $(1.5-2 \mathrm{~Sv})$ and year II $(1.5 \mathrm{~Sv})$, weaker in year III (less than $0.5 \mathrm{~Sv}$ ) (Figs. 3b-d). The most striking difference from the $\mathrm{GM}$ is the presence of mesoscale eddies in the Catalan Sea in year II (eddy B), north of Minorca (eddy C) and northwest of
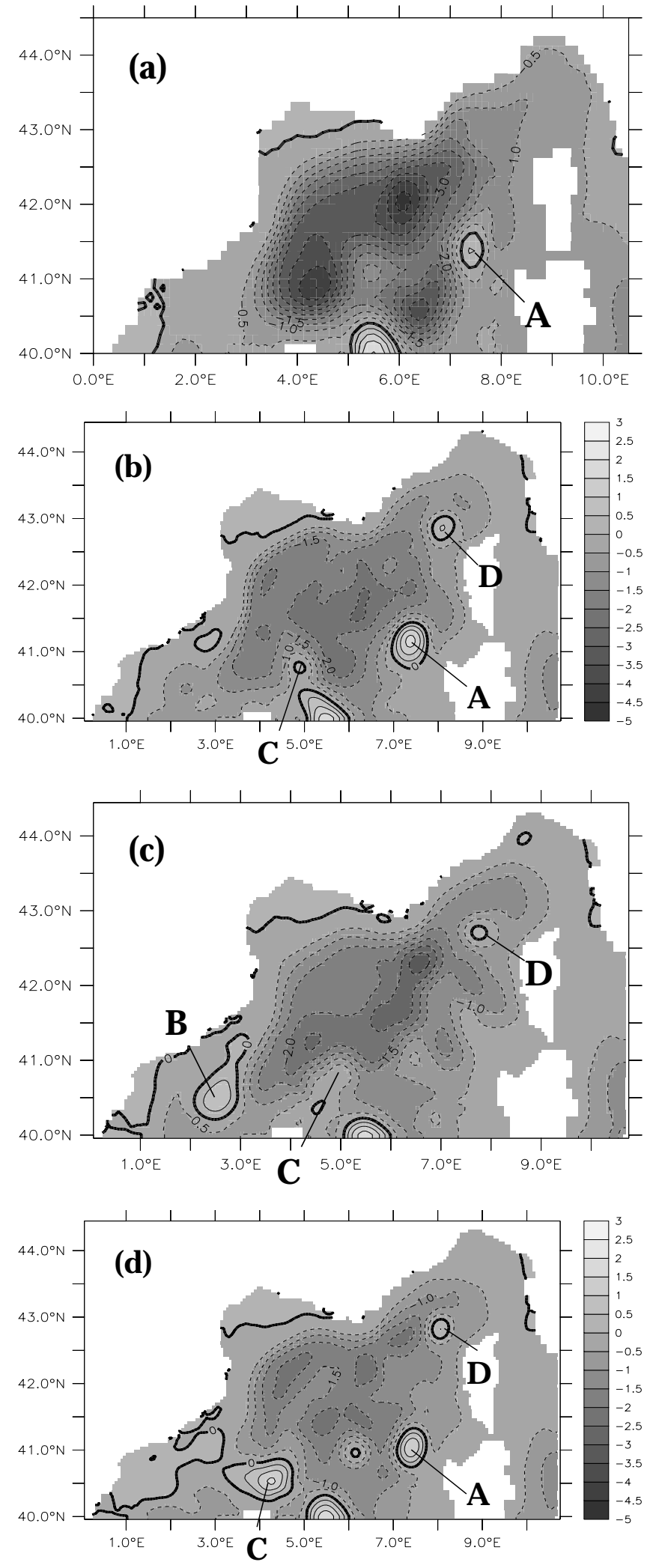

Fig. 3. Annual mean barotropic stream function for: (a) the GM; (b) the RM, year I; (c) year II; (d) year III. Isoline units are in Sverdrups (Sv), 0.5-Sv intervals. (A), (B), (C) and (D) denote eddies. 
Corsica (eddy D) during the three years. This mesoscale activity will be discussed in detail in the following subsections.

\subsection{Mesoscale circulation}

We divided the RM domain into four subdomains, as shown in Fig. 2.

4.3.1 Eastern Algero Provençal basin $\left(6^{\circ} \mathrm{E}-9^{\circ} \mathrm{E}, 40^{\circ} \mathrm{N}-\right.$ $43^{\circ} \mathrm{N}$, region (1) in Fig. 2)

The west Corsican current (hereafter WCC), which flows northwards along the east Sardinian and Corsican coasts (Millot, 1987), is highly unstable in the RM. It can be identified as a $50-\mathrm{km}$-wide current with large-scale meanders which can deflect the current as far as $150 \mathrm{~km}$ off the coast. Anticyclonic eddies (denoted A and B in Fig. 4) are generated by the instability of the WCC. After their formation, these deep eddies are trapped by topography and form quasi-permanent features of the mesoscale circulation. In the southern part $\left(\sim 41^{\circ} \mathrm{N}\right)$, anticyclonic eddies (denoted $\mathrm{B}$ ) are generated by the inflow of warm water $\left(T \sim 13.8^{\circ} \mathrm{C}\right)$ coming from the Algerian basin. These warm eddies may interact with anticyclonic eddies propagating eastwards from the Catalan Sea. As shown in Fig. 4b, a warm eddy (B) is squeezed against the Sardinian coast by eddy $C$ which comes from the west. Then eddy B propagates along the shelf break between $40.5^{\circ} \mathrm{N}$ and $41^{\circ} \mathrm{N}$ (Figs. $4 \mathrm{c}$ and d), trapped by the topographical beta effect, and detaches from the coast north of $41^{\circ} \mathrm{N}$ (Figs. 4e and f). Since eddy B reaches the bottom of the Mediterranean Sea, its trajectory is strongly constrained by the bottom topography. It cannot propagate north of $42.5^{\circ} \mathrm{N}$, because of the topographic rise from $2700 \mathrm{~m}$ to $2500 \mathrm{~m}$ near $7^{\circ} \mathrm{E} 42.5^{\circ} \mathrm{N}$. The same occurs for eddy A which cannot propagate north of $43^{\circ} \mathrm{N}$, also because of the topographic rise from $2500 \mathrm{~m}$ to $2300 \mathrm{~m}$. The size $(\sim 50 \mathrm{~km})$ of the eddies of type B is in good agreement those observed in the sea-surface temperature data by Wald (1985) and Millot (1991).

A potential mechanism is baroclinic instability. It is favoured by the high resolution of the RM which resolves the first radius of deformation. Another effect may be the width of the current flowing into the RM domain at the southern open boundary. This specified current is relatively wide, owing to the low resolution of the GM and to the monthly averaging of the GM outputs. However, the use of a higher temporal sampling (weekly instead of monthly) at the southern open boundary imposes a thinner northward current, but does not change significantly the mesoscale variability in the region. Furthermore, a qualitatively similar mesoscale variability was observed in a $1 / 16^{\circ} \cdot 1 / 16^{\circ}$ MERCATOR model of the whole Mediterranean Sea (K. Béranger, personal communication). This tends to demonstrate that the influence of the southern open boundary on the results is not crucial.

Other processes related to the instability of the Levantine Intermediate Water (LIW) vein, which flows along Sardinia, may generate mesoscale variability in this region. First, the
LIW vein advected northwards into the RM domain is unstable, because of the adjustment to the RM's smaller-scale dynamics. Second, this intermediate water vein may become unstable and generate lenses at low Rossby numbers (Sadoux et al., 2000), which is the case in the RM and GM simulation $\left(R_{o}=U / f L \sim 10^{-2}\right)$. Last, "leddies" (LIW eddies) can be generated southwest of Sardinia (near $7.5^{\circ}$ E $39^{\circ} \mathrm{N}$ ) when the LIW vein turns from flowing westwards to northwards, in order to balance the zonal momentum budget (Pichevin and Nof, 1996). These "leddies" then propagate northwestwards under the combined effects of advection, which is governed by the mean flow, planetary vorticity and topography. They enter the RM domain between $6^{\circ} \mathrm{E}$ and the coast of Sardinia. This process may generate another source of mesoscale variability in the RM.

Near the north Corsican coast $\left(8.8^{\circ} \mathrm{E} 42.5^{\circ} \mathrm{N}\right)$, the WCC remains offshore most of the time (Fig. 4). It is deflected westwards by a quasi-permanent anticyclonic eddy (A, Fig. 4) and may split into two branches: the west branch, reaching the Provence coast near $6^{\circ} \mathrm{E} 42.6^{\circ} \mathrm{N}$; and the east branch, following the coast of north Corsica near $43^{\circ} \mathrm{N}$ (Figs. 4d and e).

\subsubsection{The Ligurian Sea $\left(6^{\circ} \mathrm{E}-11.5^{\circ} \mathrm{E}, 42.8^{\circ} \mathrm{N}-44.5^{\circ} \mathrm{N}\right.$, re- gion (2) in Fig. 2)}

Mesoscale activity in the Ligurian Sea is compared to measurements of the 1981-1982 DYOME experiment (TaupierLetage et Millot, 1986; hereafter referred to as TLM86). Based on current measurements at several sites, these authors showed that baroclinic mesoscale activity (limited to the top $300 \mathrm{~m}$ ) was quasi-permanent in the southern Ligurian Sea during this period (Fig. 3 of TLM86). It is also the case in the RM, as shown by the stick-vector plot at point A northeast of Corsica (see Fig. 6a) in Fig. 5. The mesoscale currents are less intense in the RM than in the observations, especially in winter. This relatively low mesoscale activity is likely due to the climatological forcing, which does not include wind burst and associated cooling events. Closer to the shelf break along the Corsican coast, the RM currents and the TLM86 observations are in relatively good agreement. Both display an along-slope baroclinic coastal WCC, oriented to the northeast in the southern part (point B in Fig. 6a), and to the north in the northern part (point $\mathrm{C}$ in Fig. 6a; not shown). The surface velocities are $\sim 5 \mathrm{~cm} / \mathrm{s}$ weaker in the model.

The circulation in the eastern and northeastern Ligurian Sea is linked to the east Corsican current (ECC). Its transport through the Corsica channel in the RM is highly constrained by the GM transport values. The magnitude of the annual mean transport is in good agreement $(0.5 \mathrm{~Sv})$ with observations $(0.36 \mathrm{~Sv}$ ) in the GM (and consequently in the RM). The amplitude of the seasonal cycle is weaker in the model but in phase with the observations (Fig. 7). This may be due to the smooth ECMWF wind forcing, since this transport has been shown to be mostly wind forced (Herbaut et al., 1997).

Descriptions of the circulation in the northern Ligurian Sea (north of $43.5^{\circ} \mathrm{N}$ ) are scarce. The ECC has been described 


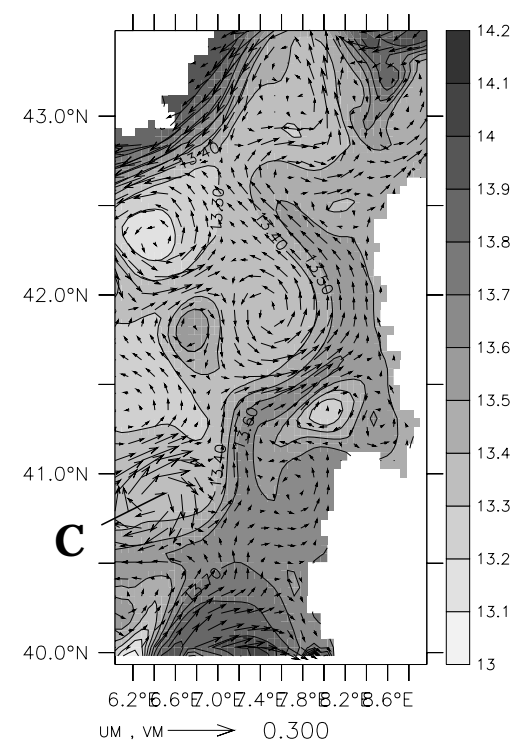

(a)

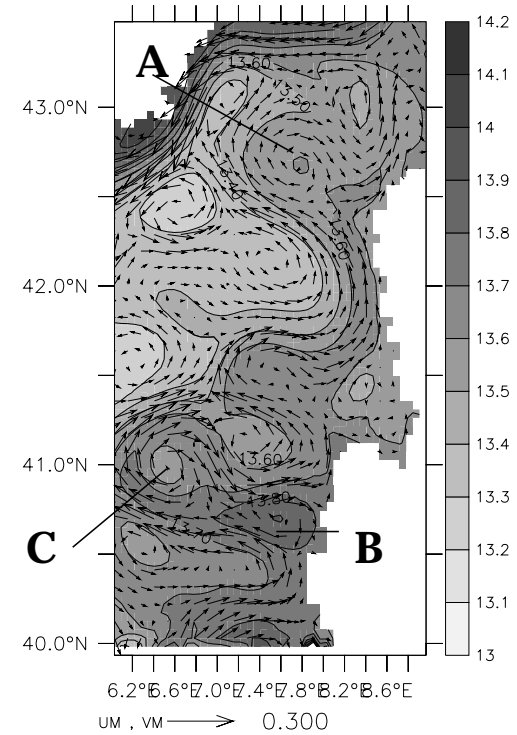

(c)

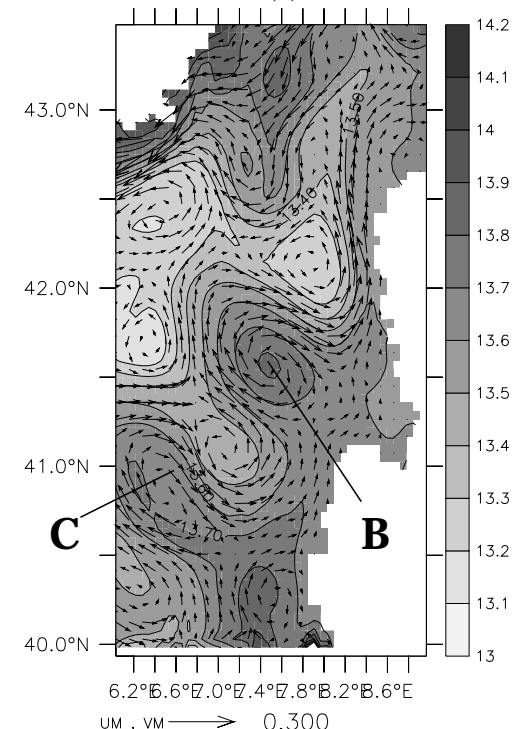

(e)

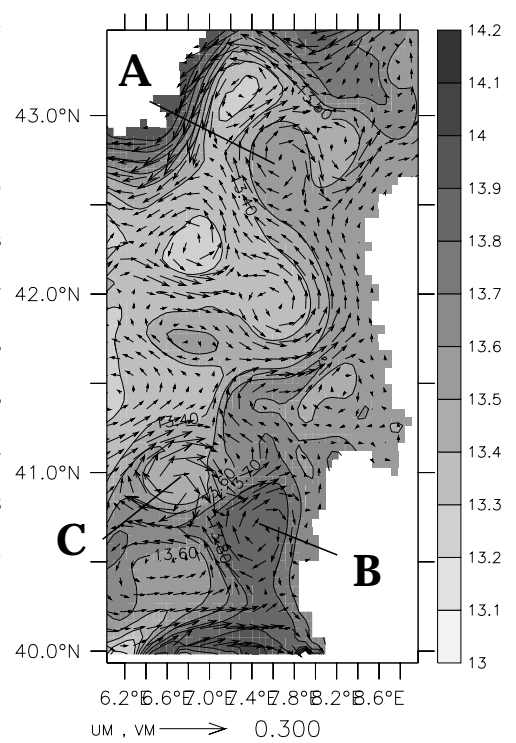

(b)

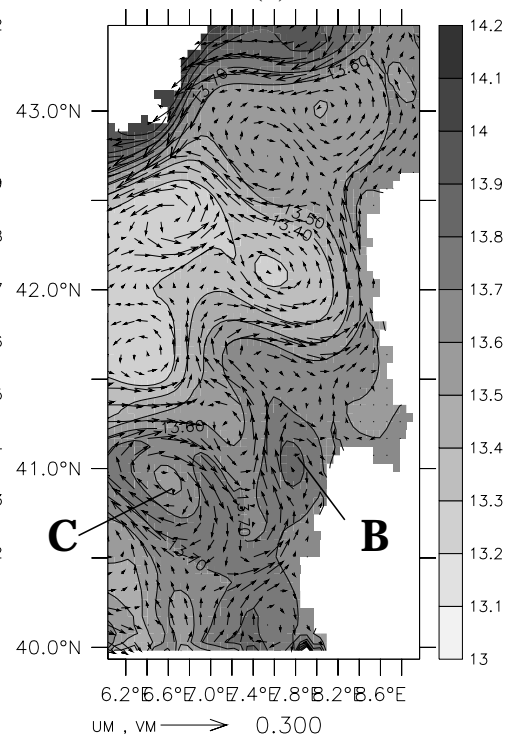

(d)

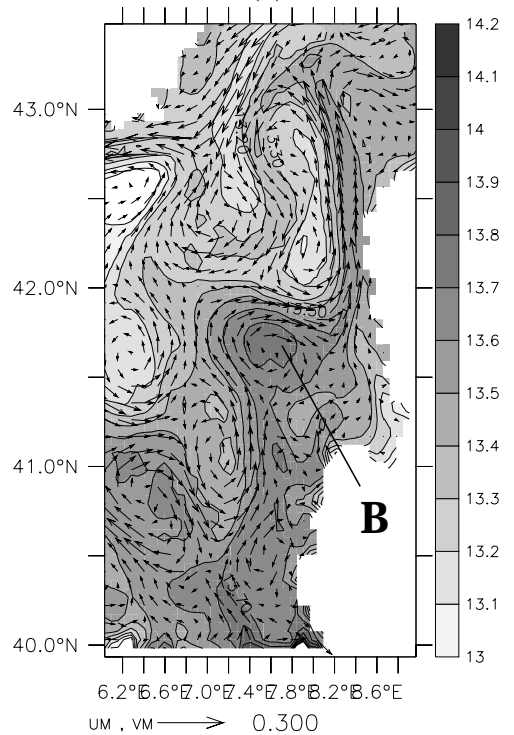

(f)

Fig. 4. Monthly mean temperature (shaded, in ${ }^{\circ} \mathrm{C}$ ) and velocity (arrows, in $\mathrm{m} / \mathrm{s}$ ) at $100 \mathrm{~m}$ in: (a) August; (b) September; (c) October; (d) November; (e) December of year II; (f) January of year III. 

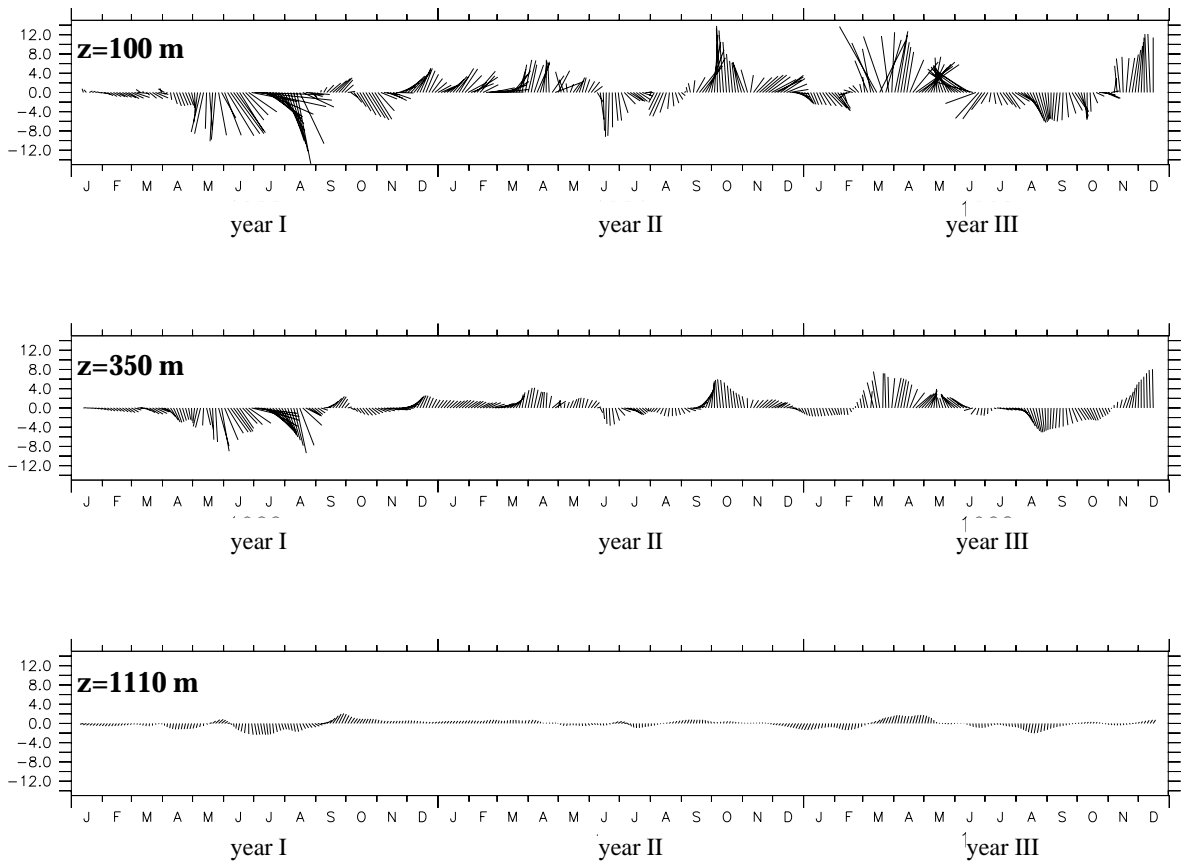

Fig. 5. Stick-vector plot at point $\mathrm{A}\left(8.6^{\circ} \mathrm{E} 43^{\circ} \mathrm{N}\right.$; see Fig. 6a) in the Ligurian Sea for three depths: $100 \mathrm{~m}, 350 \mathrm{~m}, 1110 \mathrm{~m}$.
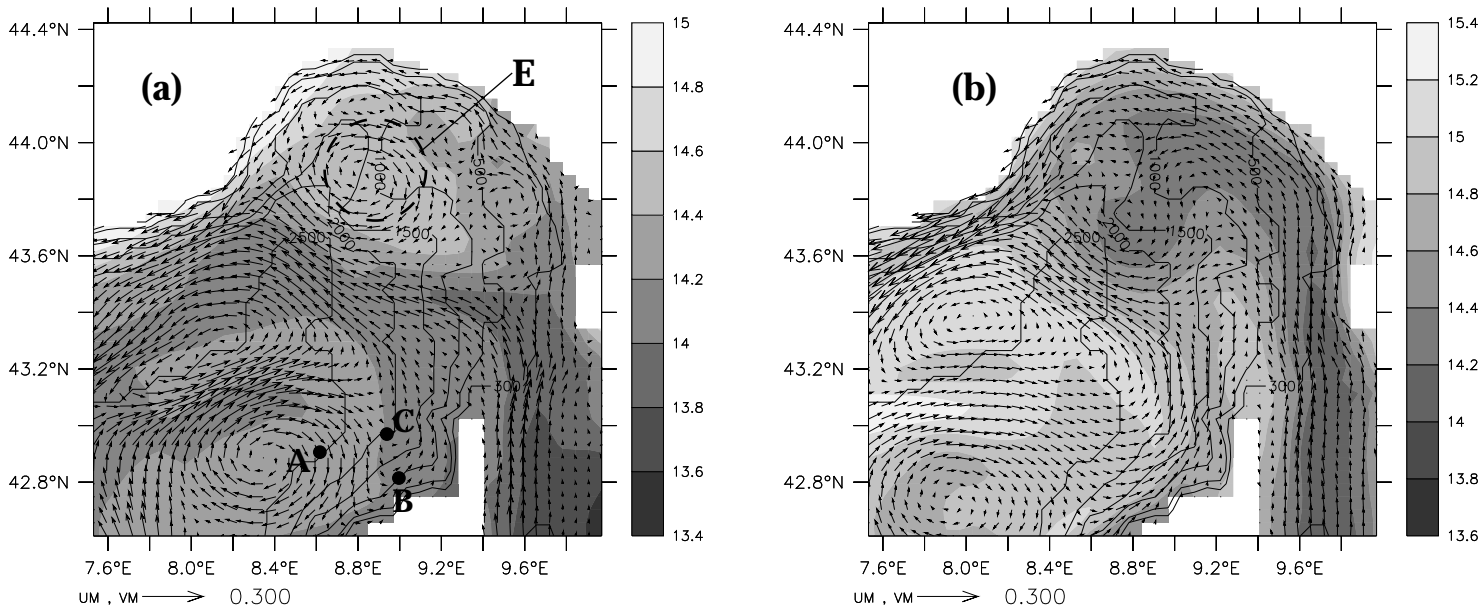

Fig. 6. Temperature (shaded, in ${ }^{\circ} \mathrm{C}$ ), velocity (arrows, in $\mathrm{cm} / \mathrm{s}$ ) at $50 \mathrm{~m}$, and bottom topography (isobaths) in the Ligurian Sea in: (a) June, year I; (b) December, year I. A, B and C denote locations of the current meters during the PRIMO-0 experiment (Taupier-Letage and Millot, 1986). (E) denotes an anticyclonic eddy. 300-m, 500-m, 1000-m, 1500-m, 2000-m, 2500-m isobaths are also plotted.

as a coastal current (Millot, 1987) which follows the coast of the Gulf of Genoa throughout the year. It is the case in the GM, but the variability of the ECC is strong in the RM. First, the ECC cannot be identified as a single current. It splits into several veins north of $43.5^{\circ} \mathrm{N}$. In spring and summer, the main vein north of the Corsica channel is oriented to the northwest until it reaches the Provence coast (Fig. 6a). This behaviour is reproduced every year. The circulation on the Ligurian shelf is quite variable. A northward flow along the coast can be identified in Fig. 6a. This flow displays meanders in winter and spring. Between the end of summer and the beginning of winter, i.e. when the northward transport of the ECC is low, the ECC forms a single vein which spreads over the wide shelf (Fig. 6b).

An anticyclonic eddy of $\sim 50-\mathrm{km}$ diameter (denoted $\mathrm{E}$ in Fig. 6a) develops in the Gulf of Genoa each year at the end of spring. This baroclinic ( $600 \mathrm{~m}$ deep) eddy may be due to the instability of the ECC vein. Note that the very steep bottom slope, indicated by the closely packed isobaths, may trap the flow. The eddy dissipates in early or late summer, depending on the year. A similar type of eddy was also simulated by the MERCATOR model which uses the same bottom topography as the RM (K. Béranger, personal communication). A small-scale structure containing Winter Inter- 


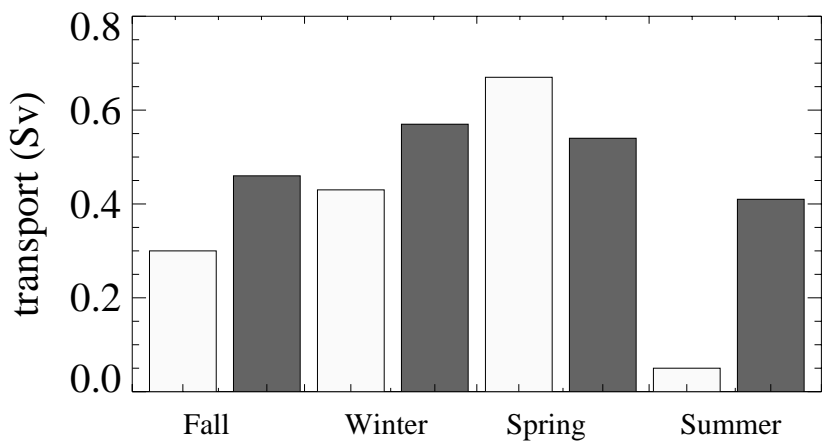

Fig. 7. Northward transport through the Corsica channel at $42.5^{\circ} \mathrm{N}$. Light-shaded values correspond to measurements (Astraldi and Gasparini, 1992); dark-shaded values correspond to GM and RM values.

mediate Water (WIW) has been observed at the same location in spring 1991 (Gasparini et al., 1999). An anticyclonic sea-level anomaly was also evident in Topex/Poseidon (T/P) and Earth Resources Satellite I (ERS-1) altimetric data during the period January-June 1993 (Ayoub, 1997). However, more observations are needed and the processes that could generate this type of eddy remain to be confirmed.

\subsubsection{The Gulf of Lions $\left(93^{\circ} \mathrm{E}-6^{\circ} \mathrm{E}, 42^{\circ} \mathrm{N}-43.5^{\circ} \mathrm{N}\right.$, region (3) in Fig. 2)}

The North current (NC), which is formed by the convergence of the ECC and WCC in the Ligurian Sea (Millot, 1987), flows along the Provence coast east of $\sim 5.3^{\circ} \mathrm{E}$ and leaves the coast where the shelf break widens. The circulation in the Gulf of Lions is oriented southwestwards by this current (Millot, 1990). The westward flow on the shelf is enhanced by freshwater input by the Rhone River plume. On the shelf, nearshore mesoscale activity is due to coastal upwelling cells forced by the mistral and tramontane winds (Millot, 1979). Offshore, mesoscale activity is associated with the meandering of the NC due to baroclinic instability (Conan and Millot, 1995; Flexas et al., 2002).

The NC displays realistic features in the RM. The baroclinic transport of the $\mathrm{NC}$ through a meridional section at $5^{\circ} \mathrm{E}$ is plotted in Fig. 8. Its annual mean $(1.9 \mathrm{~Sv}$ with an interannual variability of $\pm 0.1 \mathrm{~Sv}$ ) and seasonal cycle (maximum transport in winter $(\sim 2.2 \mathrm{~Sv})$ and minimum in summer $(\sim 1.7 \mathrm{~Sv}))$ are in relatively good agreement with previous estimations (Albérola et al., 1995; Conan et al., 1995; Béthoux et al., 1988). Though it agrees more closely with the observations, the transport of the $\mathrm{NC}$ in the RM is still $\sim 0.5-1 \mathrm{~Sv}$ too high. This may be due to the relatively large width of the current which is $\sim 25 \mathrm{~km}$ in the observations (Alberola et al., 1995), $\sim 40 \mathrm{~km}$ in the RM, and $\sim 70 \mathrm{~km}$ in the GM and to the high ECC transport in both the GM and the RM. Due to the high spatial resolution of the RM, the baroclinic instability of the NC is able to develop. Meanders of length scales ranging between $\sim 30$ and $110 \mathrm{~km}$ propagate southwestwards along the Ligurian coast and the Gulf of Lions' continental

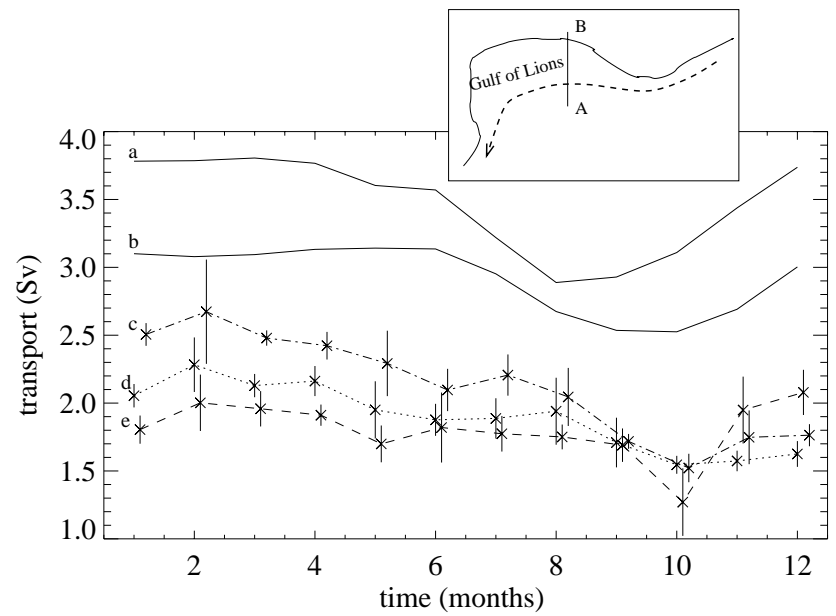

Fig. 8. Westward transport of the NC through a section (A-B) north of $\left(5^{\circ} \mathrm{E} 42.2^{\circ} \mathrm{N}\right)$ for the GM (full line) and the RM (dotted line: year I; dashed line: year II; dash-dotted line: year III). Error bars correspond to the standard deviation of the transport calculated from 3-day-mean transport values.

slope (Fig. 9). This range of spatial scales has been observed by Crépon et al. (1982) in the Ligurian Sea and by Flexas et al. (2002) in the Gulf of Lions. The phase velocity estimated from Figs. 9a and $b$ is $\sim 3-5 \mathrm{~cm} / \mathrm{s}$. This value is low compared with that inferred from early winter observations of sea-surface temperature (SST; Crépon et al., 1982) and velocity measurements (Flexas et al., 2002). However, the phase speed of the baroclinic waves is very sensitive to the vertical velocity shear (Tang, 1975) and to the model's vertical discretisation (Griffiths et al., 2000).

Spectra of the RM current velocity in the Gulf of Lions' shelf break region have been compared with the results of the March-May 1997 High-Frequency Flux Experiment (Flexas et al., 2002). The spectra display a high level of energy at periods lower than 30 days and in the 15-20 day band. At higher frequencies, no energy was found. This contrasts with previous observations (Flexas et al., 2002; Albérola et al., 1995) which show strong mesoscale activity at shorter time periods, namely at 3.5 days and 7 days.

This result can be explained as follows. The propagation of the NC meanders in the RM is quite slow compared to that of the observed instabilities, and this leads to a shift of the mesoscale variability spectrum towards lower frequencies. Furthermore, the resolution of the RM $(\sim 4.9 \mathrm{~km}$ at $43^{\circ} \mathrm{N}$ ) is not sufficient to resolve the first Rossby radius of deformation in the Gulf of Lions during the winter season. The energy near 3.5 days corresponds to small-scale meanders (Albérola et al., 1995) which are not resolved by the RM dynamics.

An index of "regional" mesoscale activity was calculated to study seasonal variations (Fig. 10). The eddy kineticenergy field was calculated from the RM velocity field at $100 \mathrm{~m}$ depth, and was spatially averaged in three different areas (Fig. 9a). The mesoscale activity displays strong intra- 

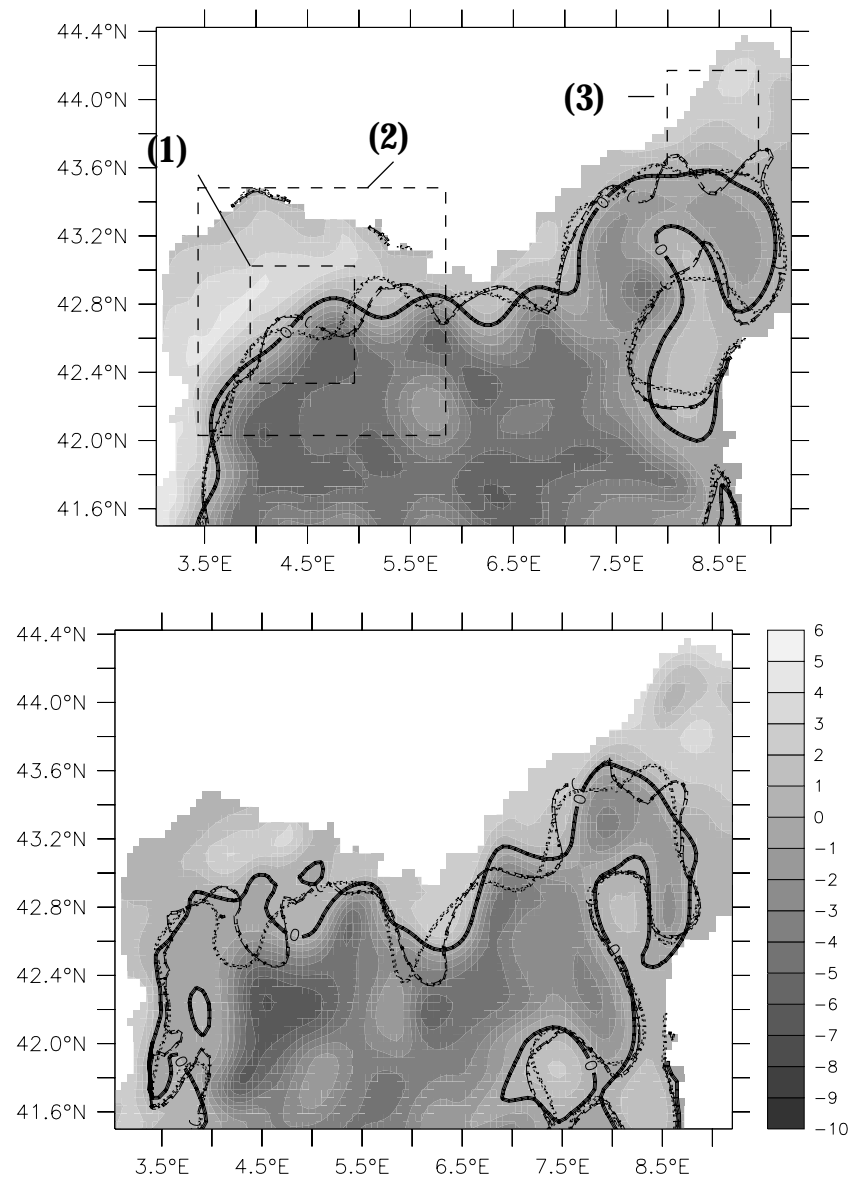

Fig. 9. RM sea-surface height (shaded, in $\mathrm{cm}$ ) and isolines for three dates: $t_{0} ; t_{0}+10$ days; $t_{0}+20$ days. (a) $t_{0}=31 / 07$, year I; (b) $t_{0}=19 / 05$, year III. Three areas are delimited by dashed lines.

seasonal and seasonal variability. A clear annual cycle could not be observed over the three years of simulation. Intense mesoscale activity in the Gulf of Lions occurs in the winters of year I (Fig. 10a) and year III (Fig. 10c), but not during year II (Fig. 10b). Mesoscale activity occurs in summer during year I, but shifts towards spring in the other years. The high mesoscale activity in the Gulf in spring-summer is correlated in time with that in the Ligurian Sea. This is not the case in winter, especially in year III of the simulation, which indicates that meandering of the $\mathrm{NC}$ in this period is not linked to a remote forcing in the Ligurian Sea. It occurs locally in the Gulf of Lions east of $\sim 6.5^{\circ} \mathrm{E}$ and it is reinforced by dense-water formation taking place in the Gulf in winter (see, Sect. 4.7). This process, linking mesoscale variability of the $\mathrm{NC}$ and dense-water formation offshore, has been observed by Albérola et al. (1995).

\subsubsection{Catalan Sea (region (4) in Fig. 2)}

Since the Gulf of Lions' shelf width decreases near the Catalonian coast, the NC remains trapped along the coast (Millot, 1987). In the GM, the NC separates from the Catalonian coast near $3^{\circ} \mathrm{E} 41.5^{\circ} \mathrm{N}$ and flows southwards towards
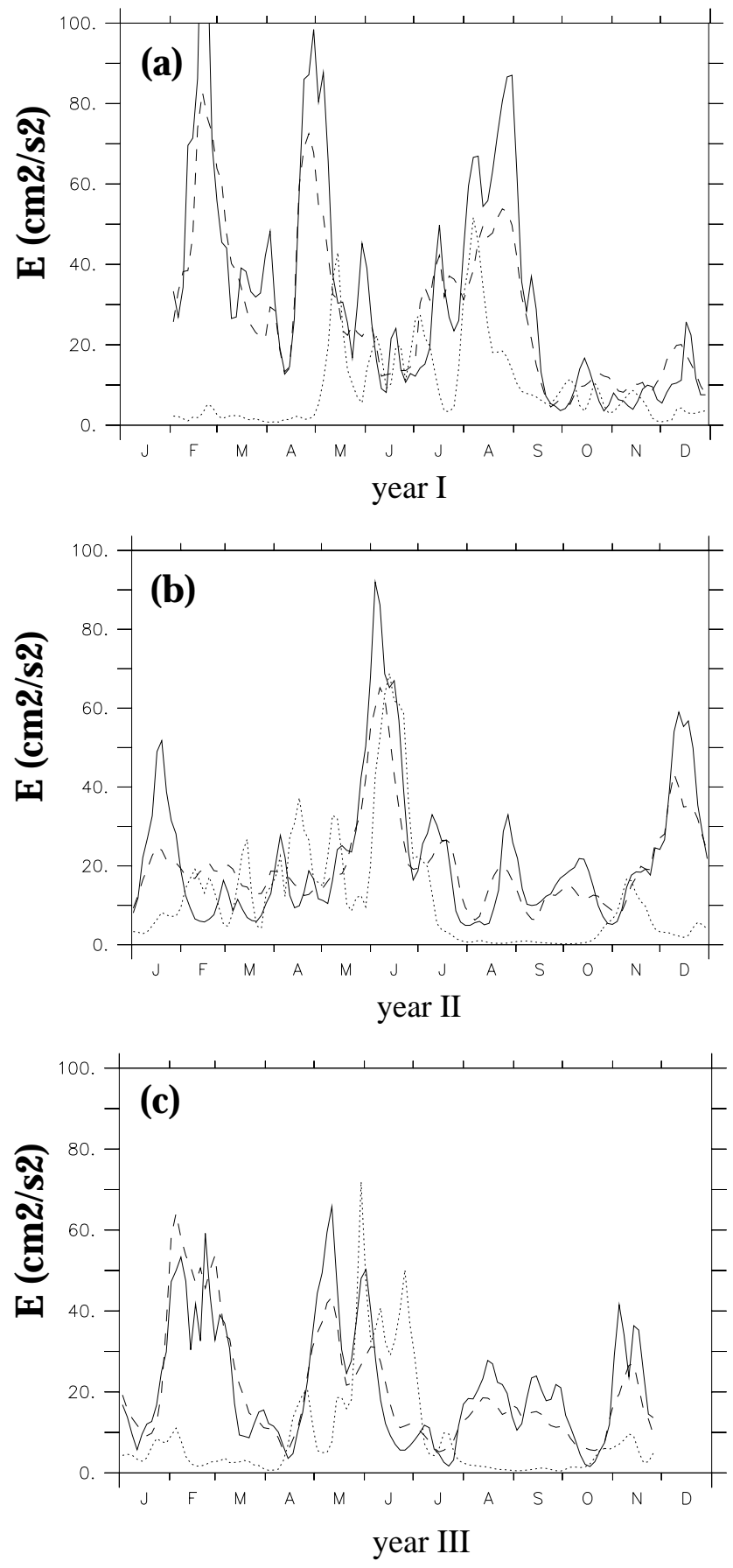

Fig. 10. Eddy kinetic energy (in $\mathrm{cm}^{2} / \mathrm{s}^{2}$ ) calculated from the RM velocity field at $100 \mathrm{~m}$ depth, and averaged horizontally over three different areas indicated in Fig. 8: (1) the Gulf of Lions' shelf break $\left(4^{\circ} \mathrm{E}-5^{\circ} \mathrm{E} 42.4^{\circ} \mathrm{N}-43^{\circ} \mathrm{N}\right)$, full line; (2) the Gulf of Lions $\left(3.5^{\circ} \mathrm{E}-5.5^{\circ} \mathrm{E} 42^{\circ} \mathrm{N}-43.5^{\circ} \mathrm{N}\right)$, dashed line; (3) the north Ligurian Sea $\left(7.8^{\circ} \mathrm{E}-8.4^{\circ} \mathrm{E} 43.6^{\circ} \mathrm{N}-44.2^{\circ} \mathrm{N}\right)$, dotted line. (a) year I, (b) year II, (c) year III.

Minorca (Fig. 3a). This behaviour is reproduced in the RM owing to the GM forcing at the southern open boundary. Previous observations (Font et al., 1995; Millot, 1987; Pinot et al., 2002) described an NC which flows along the shelf as 

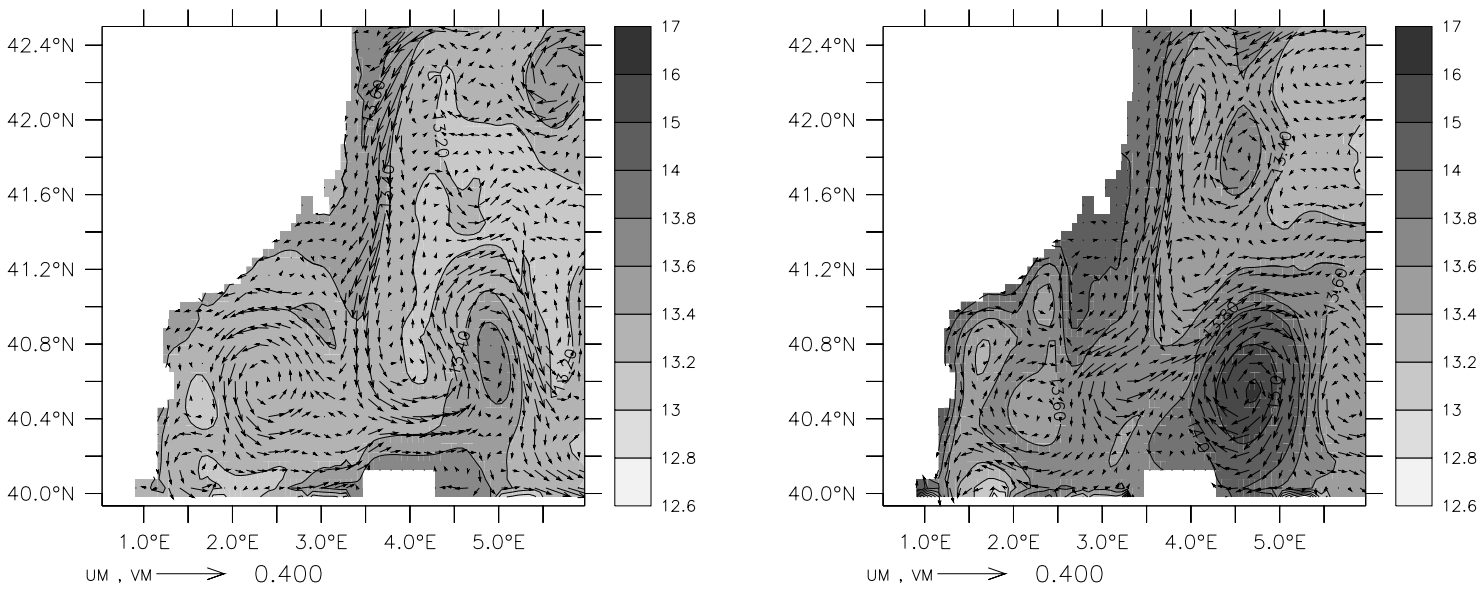

Fig. 11. Temperature (shaded, isotherms every $0.2^{\circ} \mathrm{C}$ ) and velocity (arrows, in $\mathrm{m} / \mathrm{s}$ ) at $100 \mathrm{~m}$ in the northern Balearic Sea. (a) August, year I, (b) December, year II.

far south as $40^{\circ} \mathrm{N}$. Consequently, the mean flow of the $\mathrm{NC}$ and its mesoscale variability along the Catalonian coast near $\left(1.35^{\circ} \mathrm{E} 40.7^{\circ} \mathrm{N}\right)$ are low compared with observations (Font et al., 1995).

However, mesoscale activity offshore is intense in the RM. Several cyclonic and anticyclonic eddies are generated by the baroclinic instability of the NC south of $41.6^{\circ} \mathrm{N}$ as it leaves the Catalonian coast (Fig. 11). Anticyclonic eddies are formed near the coast when the NC meanders and detaches from the shelf break. These eddies propagate downstream; the small ones $(\sim 40 \mathrm{~km})$ are absorbed by the mean NC current, the largest one $(\sim 60 \mathrm{~km})$ propagates southwards until it reaches the southern open boundary and dissipates within $\sim 1$ year.

One such anticyclonic eddy was observed in the Gulf of Valencia near the coast at $\sim 40.5^{\circ} \mathrm{N}$ (Font et al., 1995). Intense eddies may propagate as far south as the Ibiza channel (38.6 N ; Pinot and Ganachaud, 1999). The presence of the southern open boundary at $39.9^{\circ} \mathrm{N}$ may have some influence on the dynamics of these eddies, and prevent them from propagating southwards. This eddy activity results in an eastward displacement and detachment of the NC from the Catalonian coast.

South of the separation from the Catalonian coast, the NC is deflected eastwards and forms the Balearic current (hereafter referred to as BC). The BC path is strongly perturbed by eddies that develop northeast of Minorca. The first type of anticyclonic eddy is generated in summer by the instability of the BC (Fig. 11a) and may be enhanced by the wind shear in summer (Millot, 1999). It propagates northeastwards and crosses the basin. A large $(\sim 60-80 \mathrm{~km})$ anticyclonic eddy is formed east of Minorca, owing to the northward flow of warm water in late summer-early winter (Fig. 11b). This eddy interacts with the mean eddy field and remains in the same area (between $3^{\circ} \mathrm{E}$ and $6^{\circ} \mathrm{E}$, south of $41.2^{\circ} \mathrm{N}$ ) during the rest of the simulation ( $\sim 2$ years). Note that the eddy is relatively close to the southern open boundary, which may influence its dynamics.

\subsection{Influence of Rhone River runoff}

We complete this description of the surface mesoscale circulation in the RM with an analysis of the influence of the Rhone River runoff. Freshwater input from the Rhone River mouth (at $5^{\circ} \mathrm{E} 43.2^{\circ} \mathrm{N}$ ) was simulated in the RM, as described in Sect. 3. In the RM, this water has a clear signature on the surface-salinity field, and its influence can be observed as far south as $\sim 40.5^{\circ} \mathrm{N}$ at the end of summer (Fig. 12a). The extent of the freshwater plume varies seasonally and depends on the wind-stress magnitude and the surface circulation. In winter and spring, the surface fresh water (characterised by a salinity lower than $37 \mathrm{PSU}$ in the RM) is confined to the shelf. The plume extends over $\sim 50 \mathrm{~km}$ southwestwards of the river mouth. The thickness of the surface fresh layer ( $\mathrm{S}<37 \mathrm{PSU}$ ) is $\sim 15 \mathrm{~m}$ deep, owing to vertical mixing by the wind. In late spring the wind strength decreases, the plume spreads westwards and reaches the Roussillon coast near $3^{\circ} \mathrm{E} 42.8^{\circ} \mathrm{N}$. Its depth decreases and is confined to the first layer. The shallow, 6-m-deep plume follows the coast as far south as $1.5^{\circ} \mathrm{E} 40.5^{\circ} \mathrm{N}$ (Fig. 12a). At the beginning of autumn, the wind stress rises and relatively fresh surface waters are mixed, so that low-salinity values are no longer observed south of the Gulf of Lions.

Over the Gulf of Lions, the seasonal cycle of the RM surface salinity is in phase with that derived from climatological observations (MEDATLAS; Brasseur et al., 1996). It reaches minimum values in spring (37.1-37.2 PSU, in the observations; 36.4 PSU, in the RM) and maximum in late autumn (37.7 PSU, in the observations; 37.4 PSU, in the observations). During the winter-1998 FETCH experiment, surfacesalinity values of $\sim 37.2 \mathrm{PSU}$, off the river mouth, and of $\sim 37.5-37.6 \mathrm{PSU}$, at $50 \mathrm{~km}$ southwestwards from the river mouth, have been measured (Estournel et al., 2001). These values are significantly higher than those in the RM, whether a seasonal cycle or a constant value of the river discharge is 


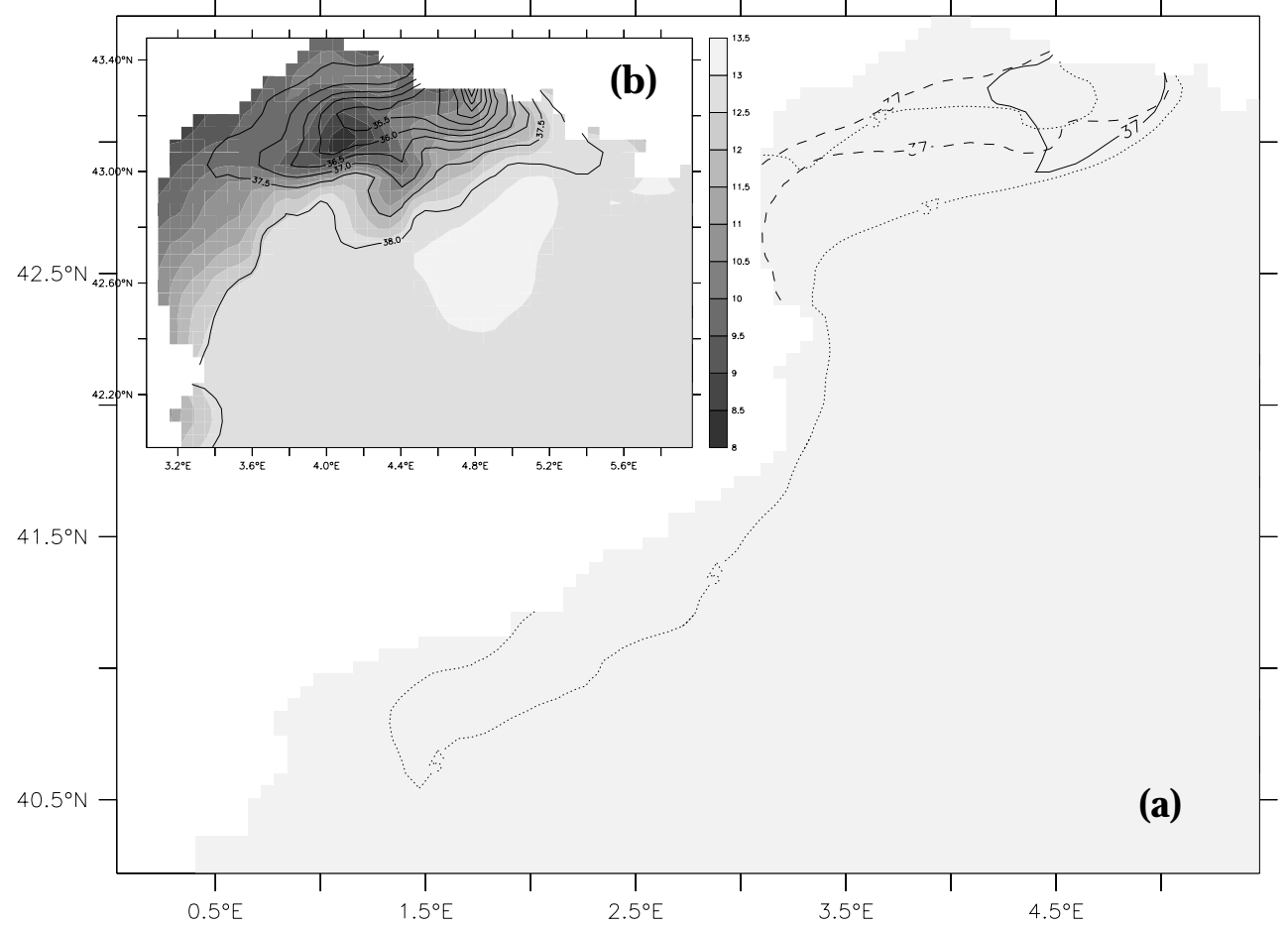

Fig. 12. (a) Extension of the fresh surface waters (delimited by the 37 PSU isohaline) in January (full line), March (dashed line), July (dotted line) of year II. (b) Sea-surface temperature (shaded, values between $8^{\circ} \mathrm{C}$ and $13.5^{\circ} \mathrm{C}$ at intervals of $0.5^{\circ} \mathrm{C}$ ) and salinity (isohalines between 33 and 38 PSU at intervals of 0.5 PSU ) in February, year II.

introduced into the model. This bias is caused by the atmospheric forcing, which does not include intense wind bursts and thus prevents vertical mixing of the fresh surface water with underlying salty water. Some salinity measurements have confirmed the presence of relatively fresh surface water south of Cape Creus. Low-salinity water ( $<<37.5$ PSU) has been observed recently off the coast of Barcelona in summer (Salat et al., 2000). Chlorophyll-rich water has been observed as far south as Cape Creus $\left(42.3^{\circ} \mathrm{N}\right)$ in SeaWiFS (Seaviewing, Wide-Field-of-view Sensor) colour data (L. Gross, personal communication). This turbid water was advected southwestwards from the Rhone River mouth; it may have contained a low-salinity signature, but information on surface salinity cannot be inferred from these satellite data. The freshwater output of the Rhone River has an impact on the air-sea heat exchange. Fresh water at the surface creates a strong stratification in the top $\sim 10 \mathrm{~m}$ of the water column, which inhibits vertical mixing. During winter, the surface water, which cannot mix with underlying water, becomes cooler and cooler. Very low temperatures are reached in the surface layer of the RM. This is confirmed by the spatial correlation between low SST $\left(\mathrm{T}<10^{\circ} \mathrm{C}\right)$ and low sea-surface salinity $(\mathrm{S}<36.5 \mathrm{PSU}$ ) patterns in January (Fig. 12b). Even though this process is likely to occur, the magnitude of this effect is very strong in the model due to the strong stratification near the surface.

In the following sections, we focus on the RM circulation of the Levantine Intermediate Water between 200 and $700 \mathrm{~m}$ depth, and of the dense water formed in winter, the Winter Intermediate Water (WIW).

\subsection{Levantine Intermediate Water (LIW) circulation}

In situ measurements show that LIW, which is formed in the Eastern Mediterranean basin, flows cyclonically around the Liguro-Provenal basin coasts. A LIW vein trapped along the shelf break circulates west of Sardinia, follows successively the west Corsican, the Ligurian, the Provence coasts, the Gulf of Lions' shelf break, and the Catalonian coast (Millot, 1987).

In the GM, the LIW found in the basin is slightly less saline (38.4 PSU) and too deep relative to the climatology (38.45 PSU). Near the coast, the LIW vein follows the cyclonic path previously described. A LIW vein of $\sim 50 \mathrm{~km}$ width follows the coasts at $\sim 300-400 \mathrm{~m}$ depth, depending on the location. The maximum salinity values in the core of the vein are 38.4-38.5 PSU, the maximum temperature in the vein varies between $13.5^{\circ} \mathrm{C}$ and $13.7^{\circ} \mathrm{C}$. In the $\mathrm{RM}$, the $\mathrm{T}$ and $\mathrm{S}$ maxima which characterise the LIW vein are quite well marked. Off the Provence coast the LIW vein is identified by a salinity (respectively, temperature) maximum of 38.44 38.45 PSU (resp. 13.3-13.4 ${ }^{\circ} \mathrm{C}$ ) (Fig. 13). In situ measurements off Nice $\left(\sim 7^{\circ} \mathrm{E}\right)$ and Marseille $\left(\sim 5.5^{\circ} \mathrm{E}\right)$ show higher salinity (38.52-38.56 PSU) and temperature $\left(13.3-13.5^{\circ} \mathrm{C}\right)$ values (Albérola et al., 1995, Conan and Millot, 1995). However, the maximum values of LIW tracers decreased during 


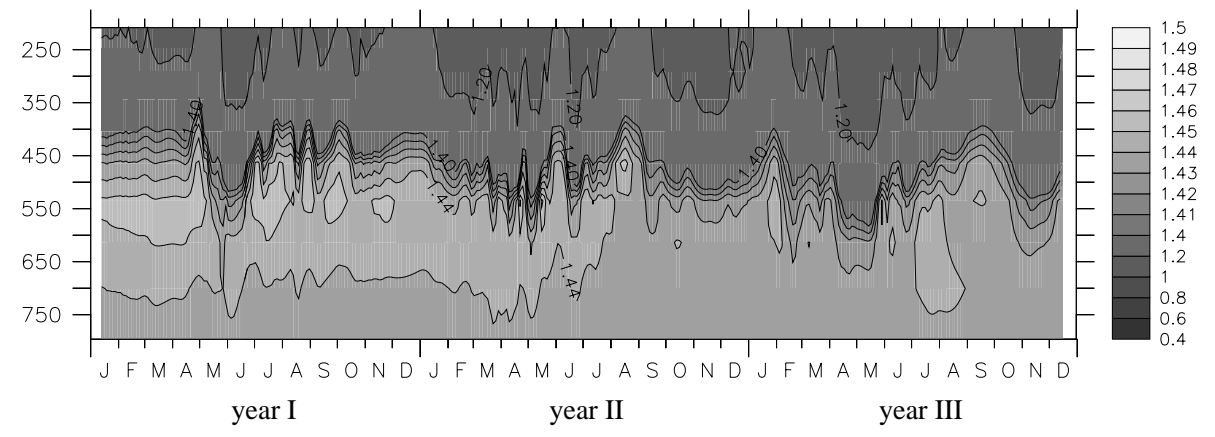

Fig. 13. Temporal evolution of the vertical profile of the salinity anomaly ( $\Delta S=S-37.0$, shaded, isohalines in PSU) near the coast of Nice $\left(7.5^{\circ} \mathrm{E} 43.3^{\circ} \mathrm{N}-43.5^{\circ} \mathrm{N}\right)$. Isohalines are spaced so as to better show the location of the LIW vein flowing along the coast.

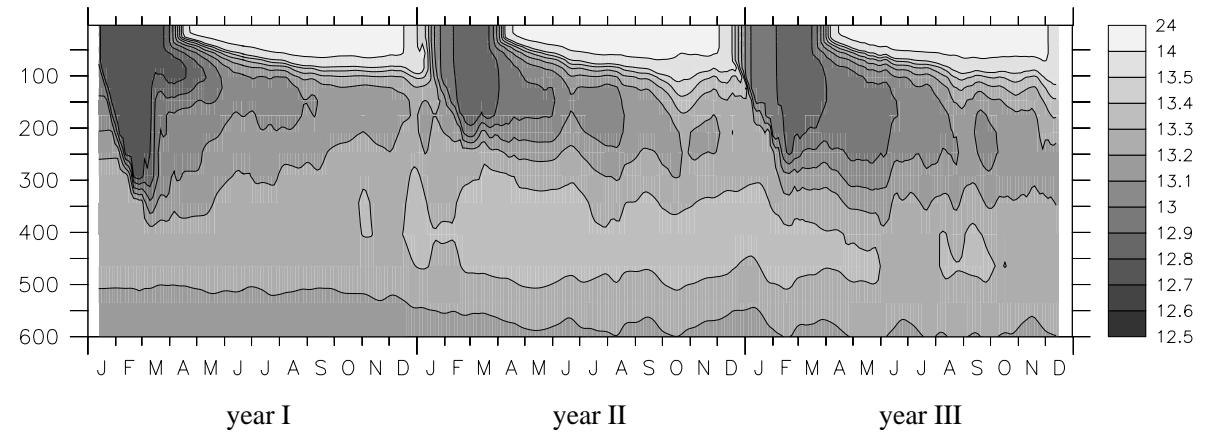

Fig. 14. Temporal evolution of the vertical profile of temperature (shaded, isotherms in $\left.{ }^{\circ} \mathrm{C}\right)$ in the central Gulf of Lions $\left(5^{\circ} \mathrm{E} 41.5^{\circ} \mathrm{N}-42^{\circ} \mathrm{N}\right)$.

years II and III in the RM (Fig. 13).

The differences between the GM and RM in respect of LIW may be explained as follows. First, different vertical diffusivities are used in the GM and RM. The GM uses constant vertical diffusivities and the RM a turbulent kineticenergy scheme (Blanke and Delecluse, 1993). Consequently, the $T$ and $S$ maxima have decreased, owing to the effect of the RM vertical mixing, and the depth of the LIW vein has slightly increased from $\sim 400 \mathrm{~m}$ in the GM (not shown) to $\sim 500 \mathrm{~m}$ in the RM (Fig. 13). Second, the high variability of the mesoscale circulation near the southern open boundary of the RM, where the LIW vein flows northwards, may enhance mixing of LIW with other water masses. Indeed, mesoscale eddies (such as those described in Sect. 4.3) may perturb the LIW vein near the Sardinian coast and advect LIW westwards into the deep ocean (Millot, 1991, Fuda et al., 2000).

\subsection{Winter Intermediate Water (WIW) circulation}

WIW ( $T \sim 12.5-13^{\circ} \mathrm{C}, S \sim 38.1-38.3 \mathrm{PSU}$ ) is formed during the winter, mainly in the north Liguro-Provençal basin, when the surface cooling is moderate, so that the cooled Mediterranean Atlantic Water (MAW) does not mix with the underlying LIW which is soon capped by the warmer and less dense MAW, and, therefore, does not interact with the atmosphere anymore. WIW formation has been observed several times in the northwestern Mediterranean basin (Albérola et al., 1995; Conan and Millot, 1995; Fuda et al., 2000).
In the central Gulf of Lions, WIW is produced due to a relatively shallow convection in the RM $(\sim 300 \mathrm{~m}$, year I, $\sim 200 \mathrm{~m}$, years II and III; Fig. 14). The WIW temperature is $\sim 12.8^{\circ} \mathrm{C}$ at the time of formation (end of March). Note that the layer of WIW is thicker during the first winter. This is probably due to the adjustment of the water column to the mixing in the RM. When the thermocline starts to develop at the end of March, WIW is mixed with the underlying LIW and with the overlying MAW. Its temperature reaches $\sim 13.1-13.2^{\circ} \mathrm{C}$ at the end of summer. The salinity of the WIW is $\sim 38.15-38.25$ PSU. These values are in good agreement with reported WIW characteristics (Fuda et al., 2000).

WIW formation along the northern coast of the LiguroProvenal basin, between Cape Creus $\left(3^{\circ} \mathrm{E} 42^{\circ} \mathrm{N}\right)$ and the Gulf of Genoa $\left(9^{\circ} \mathrm{E} 44^{\circ} \mathrm{N}\right)$, is quite similar to what occurs in the central part of the Gulf of Lions. The main difference is due to the cyclonic circulation, which advects WIW formed near the coast and traps it in the centre of the gyre. Due to the doming of the isopycnals in the central zone, vertical mixing of WIW with surface waters is enhanced, and the low temperature signature of WIW is lost more rapidly in the central zone.

Let us now describe more precisely the fate of the WIW formed over the Gulf of Lions' shelf. There, cold $(T<$ $12.5^{\circ} \mathrm{C}$ ) WIW was advected southwestwards by the mean surface flow. Owing to gravity and to the reduced shelf width, dense water cascaded in the deep ocean near $3.5^{\circ} \mathrm{E}$ $42.4^{\circ} \mathrm{N}$ (north of Cape Creus) and reached maximum depths of $\sim 600 \mathrm{~m}$. Then cold $\left(T \sim 12.8^{\circ} \mathrm{C}\right)$ and fresh $(S \sim 38 \mathrm{PSU})$ 


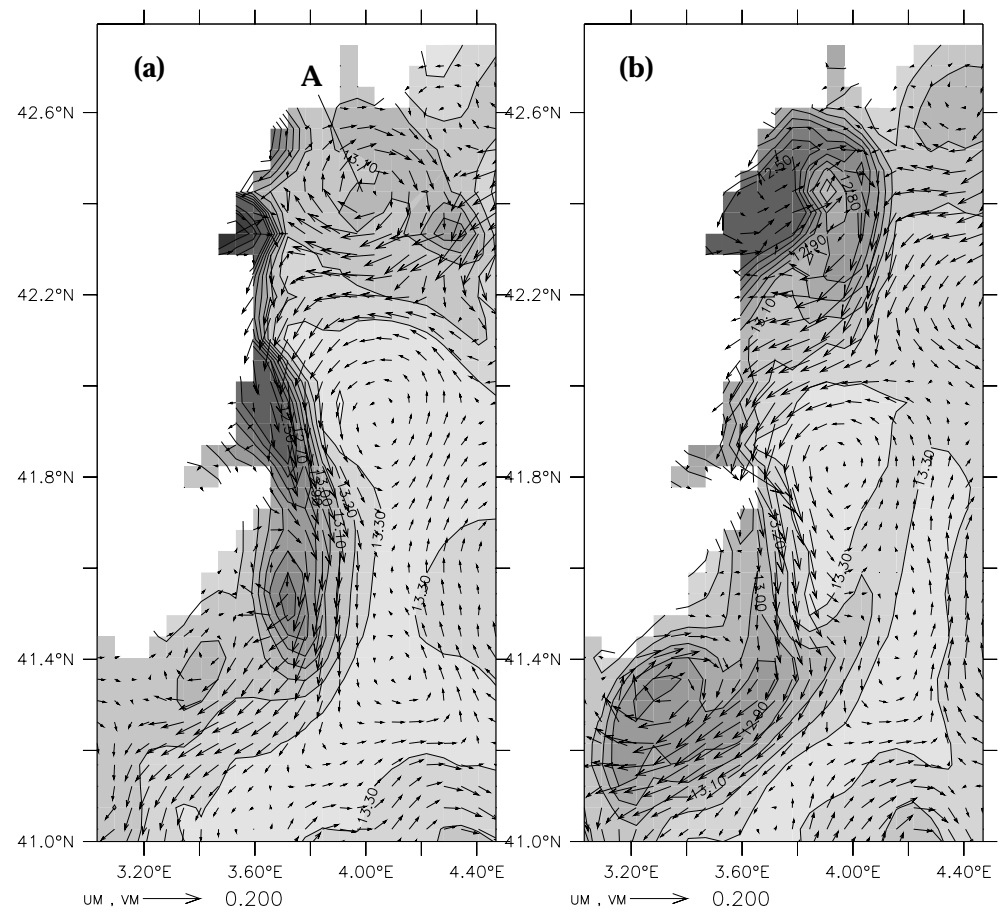

Fig. 15. Temperature (shaded, isotherms in ${ }^{\circ} \mathrm{C}$ ) and velocity (arrows, in $\mathrm{cm} / \mathrm{s}$ ) at $400 \mathrm{~m}$ in the western Gulf of Lions and northern Catalan Sea on: (a) 12 March, year II; (b) 22 March, year II. Isotherms are between $12.5^{\circ} \mathrm{C}$ and $13.3^{\circ} \mathrm{C}$ at intervals of $0.1^{\circ} \mathrm{C}$. A denotes an anticyclonic eddy propagating westwards with the NC flow.
WIW lenses were formed and advected by the NC flow.

Mesoscale activity in the NC may trap water in the Gulf of Lions. In February of years I and II, large-scale $(\sim 50 \mathrm{~km})$ meanders of the NC propagated southwestwards. An anticyclonic eddy (denoted A in Fig. 15a) was advected westward near the shelf break, close to the area of cascading. The eddy displaced the NC offshore and the nearshore flow advected WIW northwards. Most of the WIW was trapped in the western part of the Gulf of Lions and eventually a filament of WIW was advected southwestwards by the NC (Fig. 15b).

Three WIW lenses, which detached from the coast south of $41.8^{\circ} \mathrm{N}$, were observed in March of year II (Fig. 15a). These lenses become weddies (Winter Intermediate Water eddies). They became completely detached from the NC flow, propagated southwards and generated a complex eddy field in the Catalan Sea (see Sect. 4.3.4). Then WIW mixed with surrounding warmer water and may be trapped by eddies northeast of Minorca (Fig. 11b).

\subsection{Absence of Western Mediterranean Deep Water (WMDW) formation}

In neither of the GM and RM simulations was Western Mediterranean Deep Water formed in the Gulf of Lions. Several effects may explain this result. First, the salinity of the LIW in the GM (and consequently, in the RM) is $\sim 38.4$ PSU, which is a lower value than that of the climatology (38.45 PSU). Moreover, the depth of the LIW layer is slightly greater in the numerical models $(\sim 500 \mathrm{~m})$ than in the observations $(\sim 400 \mathrm{~m})$. In a study using the same model (MOM) as the GM, but with a lower resolution $\left(1 / 4^{\circ}\right)$, Castellari et al. (2000) corrected the lack of realism with respect to
LIW, by relaxing the model's winter surface-salinity in the Gulf of Lions' gyre towards a value higher than that of the MODB climatology. Thus, these authors managed to obtain deep convection in the Gulf of Lions. This parameterisation of the freshwater influx was not used in the GM nor in the RM, which, therefore, provided unrealistic LIW properties.

Second, the ECMWF atmospheric forcing for the period 1979-1993 has a very strong interannual variability (Demirov and Pinardi, 2002). This may bias the ECMWF climatology. When compared to NCEP forcing (see, Fig. 5 of Korres et al., 2000) and to re-analysis of ECMWF winter forcing (Demirov and Pinardi, 2002), winter cooling in the GM and RM simulations was found to be underestimated by $50-100 \mathrm{~W} / \mathrm{m}^{2}$. This low cooling, which is associated with relatively weak wind stress over the Gulf of Lions, also reduces preconditioning of deep-water formation. Last, the use of a low-frequency atmospheric forcing has a strong impact on the water masses that are produced in winter. Without high-frequency variability and extreme values, convection may not reach the LIW depth (Castellari et al., 2000). This effect is reinforced in a high-resolution model in which baroclinic instability acts to restratify the water column and inhibit convection (Madec et al., 1991).

\subsection{Comparison with altimetry}

We used sea-level anomaly maps from T/P-ERS-1/ERS-2 provided by CLS-Argos to compare with the RM results. Due to uncertainty in the mean elevation of the sea surface, the mean circulation over the period 1998-2000 cannot be inferred from altimetry. Furthermore, the atmospheric forcing in 1998-2000 is probably quite different from the clima- 

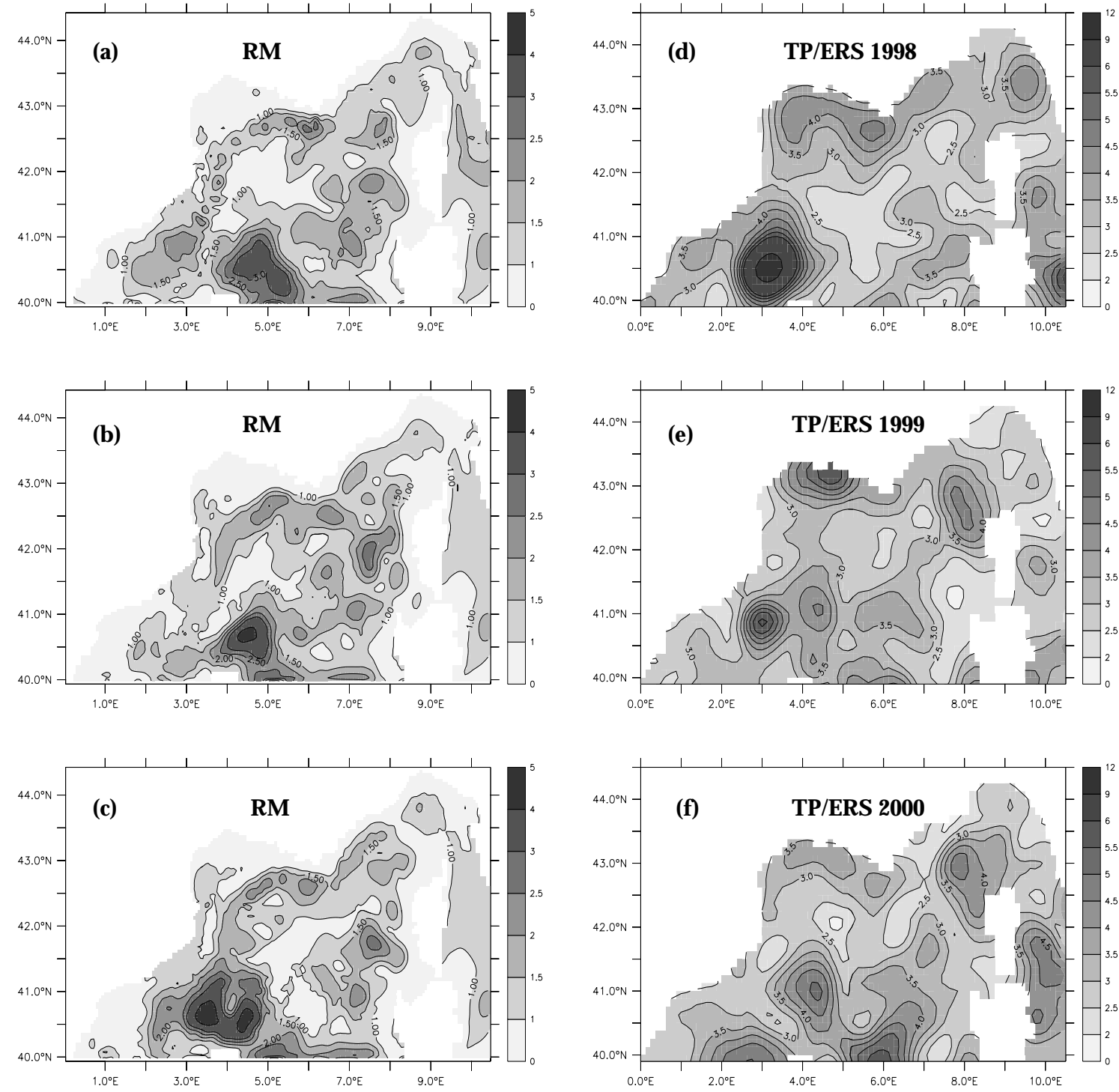

Fig. 16. Sea-surface height variability (shaded, isolines in $\mathrm{cm}$ ) from RM results (a-c) and TP/ERS data (d-f). TP/ERS maps were calculated every 6 days for the years (d) 1998, (e) 1999, (f) 2000. For each year, the SSH anomaly was calculated relative to the annual mean of the given year. For a, b, c, isolines $0,1,1.5,2,2.5,3,4$ and $5 \mathrm{~cm}$ are plotted. For d, e, f isolines 0, 2, 2.5, 3, 3.5, 4, 4.5, 5, 6, 9 and 12 cm are plotted.

tology we used, so we only compare the variability of the measured sea-surface height with that of the RM.

Along-track altimetric data from T/P and ERS have been combined to provide sea-surface height (hereafter $\mathrm{SSH}$ ) anomaly maps of the Mediterranean Sea at a resolution of $1 / 8^{\circ} \cdot 1 / 8^{\circ}$ every 7 days during the years $1998,1999,2000$ (CLS Argos, personal communication). We calculated the SSH variability for each year from these data. For each map, the mean sea level over the area $0^{\circ} \mathrm{E}-10.5^{\circ} \mathrm{E} 39.9^{\circ} \mathrm{N}-$ $45^{\circ} \mathrm{N}$ was subtracted in such a way as to filter out meansea-level temporal variations, which contain the large-scale steric-height signal. The same filtering was performed on the RM SSH fields which do not include steric-height variations. Once this filtering was done, SSH variability was calculated relative to the annual mean SSH anomaly of each given year.
The results are presented in Fig. 16 ( $a-c$ for the RM and $d-f$ for the TP/ERS data).

Despite the strong interannual variability both in the observations and the RM, some structures are qualitatively similar. There is a strong signal $(\sim 3-3.5 \mathrm{~cm})$ in the Gulf of Lions, a rather weak signal $(\sim 2 \mathrm{~cm})$ in the central part of the Gulf of Lions, a strong signal $(\sim 3.5-4 \mathrm{~cm})$ west of Corsica in 1999 and 2000, a strong signal in the Balearic Sea, north $(\sim 4 \mathrm{~cm}$ in $1999,5 \mathrm{~cm}$ in 2000$)$ and northeast $(\sim 9-10 \mathrm{~cm}$ in 1998 , $\sim 6 \mathrm{~cm}$ in 1999) of Minorca. In the Ligurian Sea, the SSH variability was strong $(\sim 3.5 \mathrm{~cm})$ in 1998 , low in 1999 and 2000. The overall level of SSH variability is much lower in the RM. Extreme values reach only $4-5 \mathrm{~cm}$ instead of the $9-12 \mathrm{~cm}$ in the observations. The background variability is less than $1 \mathrm{~cm}$ in the RM and always greater than $2-2.5 \mathrm{~cm}$ 
in the observational data. Despite the low levels of variability, several mesoscale patterns are quite similar to those observed. SSH variability is relatively high $(\sim 1-1.5 \mathrm{~cm})$ along the NC path, with a maximum $(\sim 2 \mathrm{~cm})$ south of Toulon $\left(\sim 6^{\circ} \mathrm{E} 43^{\circ} \mathrm{N}\right)$ in years II (Fig. 16b) and III (Fig. 16c). Similar structures can be observed in 1998 and 2000 (Figs. 16d and $\mathrm{f})$. The highest signal $(\sim 3-4 \mathrm{~cm})$ is in the Catalan Sea, north and northeast of Minorca, which is in good agreement with the observations. The high variability northwest of Sardinia $\left(\sim 7.5^{\circ} \mathrm{E} 42^{\circ} \mathrm{N}\right)$ in the $\mathrm{RM}$ is south of the maximum observed in the data $\left(\sim 42.5^{\circ} \mathrm{N}-43^{\circ} \mathrm{N}\right)$ in 1999 and 2000. Note also the low SSH on the Gulf of Lions' shelf in the RM compared to the observations. This may indicate low variability of the RM dynamics on the shelf, which is due to the lack of temporal and spatial variability in the wind field (Estournel et al., 2001). However, the quality of the data close to the coast is questionable (Echevin, 1998).

\section{Conclusions}

The large-scale and mesoscale circulation of the northwestern Mediterranean Sea was simulated with the OPA7 primitive-equation circulation model $(\mathrm{RM})$ embedded in a general circulation model (GM) of the Mediterranean Sea. A simulation forced by monthly climatological atmospheric forcing was performed. The good agreement between the RM large-scale and mesoscale circulation and observations reported in the literature demonstrate that the strategy of downscaling by model embedment is clearly feasible in the framework of the Mediterranean Forecast Pilot Project.

The results are summarised in the following. The largescale circulation in the Liguro-Provençal basin is in good agreement with observed features reported in the literature. The circulation is cyclonic over the RM domain. The gyre is forced by the wind stress and heat fluxes in the Gulf of Lions and alimented by the west Corsican current (WCC), which flows northwards east of Sardinia, and by the east Corsican current (ECC), which flows northwards through the Corsica channel.

The ECC is well marked in the RM. Its transport varies between $0.25 \mathrm{~Sv}$ (end of summer) and $0.6 \mathrm{~Sv}$ (end of winter), which is in relatively good agreement with observations (Astraldi and Gasparini, 1992). It veers to the west in springsummer as it exits the Corsica channel.

The WCC path cannot be identified as a well-defined current. It is perturbed by instabilities during all seasons. This current transports $\sim 1 \mathrm{~Sv}$ northwards annually. Approximately half of the flow follows the Corsican coast and meets the ECC north of Corsica. The other half crosses the Ligurian Sea northwestwards and meets the Provence coast near $7.5^{\circ} \mathrm{E}$.

The NC, formed by the convergence of the WCC and ECC along the Provence coast, is well defined in the RM. The mean flow follows the Provence coast and the Gulf of $\mathrm{Li}$ ons' shelf break. The seasonal cycle of the NC transport shows maximum values in late winter $(\sim 2.3 \mathrm{~Sv})$ and mini- mum $(\sim 1.5 \mathrm{~Sv})$ in fall, in relatively good agreement with previous observations (Albérola et al., 1995). The NC detaches from the north Catalonian coast (near $3^{\circ} \mathrm{E} 41.5^{\circ} \mathrm{N}-42^{\circ} \mathrm{N}$ ) most of the time. This behaviour, which is not confirmed by available observations (which are relatively few), seems to be forced by the open boundary condition of the RM in the southwest, which strongly depends on the GM solution.

The mesoscale activity is intense in the RM simulation. The WCC is highly unstable. Northward advection of warm water from the Algerian basin generates several eddies, and eddies generated in the Catalan Sea propagate eastwards with the Balearic current and interact with the WCC. The mesoscale activity is quite strong in the eastern Ligurian Sea, with the occurrence of small cyclonic eddies on the Gulf of Genoa's shelf, and with the occurrence of a large anticyclonic eddy in the Gulf of Genoa. Mesoscale activity in the ECC and WCC regions propagates to the NC area with the cyclonic flow. Meandering of the NC, owing to baroclinic instability, is observed. The meander length scales are in good agreement with those of previous satellite observations. However, phase velocities of the instabilities are slower than those inferred from observations (Crépon et al., 1982, Flexas et al., 2002). The mesoscale circulation is very intense in the Catalannorth Balearic Sea. Mesoscale eddies are generated when the $\mathrm{NC}$ leaves the Catalonian coast near $\left(3^{\circ} \mathrm{E}\right.$ $41.5^{\circ} \mathrm{N}-42^{\circ} \mathrm{N}$ ). These eddies are enhanced in winter when the WIW formed over the Gulf of Lions' shelf is advected southwards with the flow in the form of dense water lenses, also named "weddies" (Pinot and Ganachaud, 1999). These anticyclonic eddies remain vigorous for several months and interact with quasi-permanent eddies northeast of Minorca and with the northward-propagating eddies generated by the Algerian Current instabilities. This complex eddy field may deflect the NC path eastwards and the Balearic current north of the Balearic Islands.

New field observations are necessary to further validate (or invalidate) the RM results. Several regions remain poorly investigated. The mean and mesoscale circulation along the west coasts of Corsica and Sardinia is not well known. The place where the ECC and the WCC merge is not well known. Even though the ECC transport has been measured during several years, the circulation in the Gulf of Genoa has not been described precisely in the literature. No observational studies have described the interaction of the NC with "weddies" in the Catalan Sea.

Altimetric data provide useful information on the mesoscale circulation. However, the repetition period of the satellite tracks (9.96 days for T/P, 35 days for ERS) and the distance between neighbouring tracks is sufficient for open-ocean mesoscale activity to be observed, but not for the mesoscale activity of the relatively narrow Mediterranean boundary currents. A rigorous validation of the modelled coastal-current variability with altimetric data would imply an analysis of the data along the altimeter tracks which intersect the currents, instead of the use of two-dimensional maps produced by optimal interpolation of the along-track data on a regular grid. Such an along-track study could be done over 
a limited area (for instance, in the Gulf of Lions; Echevin, 1998), but the task would be enormous over as large a domain as that covered by the RM.

Furthermore, several modelling studies focusing on subregions of the northwestern Mediterranean are needed to clarify some of the processes involved in the RM. The persistent presence of eddies northeast of Minorca (Fig. 11), northeast of Corsica (Fig. 4), in the Gulf of Genoa in summer (Fig. 6), the deflection to the west of the ECC in winter (Fig. 11), may be sensitive to model parameterisation, such as the choice of vertical coordinates ( $z$-levels versus sigma levels) and the number of vertical levels. Such choices may influence the position of the quasi-permanent deep eddies (observed west of Sardinia and Corsica) which interact with bottom topography and modify the phase velocity of the instabilities propagating along the shelf break (Griffiths et al., 2000). Furthermore, the use of daily atmospheric forcing to force the GM and the RM models would have an impact on various processes, such as deep-water formation or the signature of the Rhone River plume on surface water.

Several questions regarding the downscaling methodology are still open. One of the major goals of the MFSPP project is the forecasting of the mesoscale and coastal circulation. We have shown that a spin-up phase of $\sim 2$ months is necessary for the RM to reach acceptable levels of kinetic energy (Fig. 1). During this spin-up phase, mesoscale activity is generated by (1) baroclinic instability due to the high spatial resolution of the RM and (2) adjustment of the initial state to the RM bottom topography. These two effects cannot be separated. Consequently, the RM circulation cannot be interpreted during the months following the initialisation of the model. The spin-up period may last more or less time, depending on the season (winter in the present case) and on the time-averaging performed on the GM data (monthly average in the present case).

An improved initial state for the RM could be obtained with the use of a data assimilation methodology. In the case of downscaling from a GM to a RM, the GM outputs can be considered as large-scale data which constrain the largescale circulation of the RM. Using such a technique, the RM and GM results would be fully consistent. However, implementing a data assimilation methodology requires adapted numerical tools, such as an adjoint model. This complex task represents a challenge for future downscaling techniques.

Acknowledgements. We thank E. Demirov and N. Pinardi, of ISAO-CNR, for providing the MOM8 data, and G. Larnicol, of CLS-Argos, for providing the TOPEX/POSEIDON and ERS1/ERS-2 altimetric data. We also thank G. Madec and K. Béranger for fruitful discussionsand R. Griffith for careful editing of the manuscript. This work was performed under the MFSPP CEE DGXII contract $n^{\circ}$ MAS3-CT98-0189 and SHOM contract $n^{\circ}$ 9987036004702925, and finalised under a post-doctoral scholarship from the Centre National d'Etudes Spatiales (CNES). Numerical calculation were performed on computers from the IDRIS computing centre.

\section{References}

Albérola, C., Millot C., and Font, J.: On the seasonal and mesoscale variabilities of the northern current during the PRIMO-0 experiment in the western Mediterranean, Oceanologica Acta, 18, 2, 163-192, 1995.

Astraldi, M. and Gasparini, G. P.: The seasonal characteristics of the circulation in the north Mediterranean basin and their relationships with atmospheric-climatic conditions, J. Geophys. Res., 97(C6), 9531-9540, 1992.

Ayoub, N.: Etude de la variabilité du niveau de la mer et de la circulation en Méditerranée à partir des données altimétriques et de champs de vent. Comparaison avec des simulations numériques., Thèse de Doctorat de l'Université Paul Sabatier, Toulouse, 1997.

Bahurel, P.: MERCATOR, developing an integrated system for operational oceanography, Proceedings of the OCEANOBS99 (solicited papers), 18-22 October 1999, St Raphaël, France, Centre National d'Etudes Spatiales, France, 1999.

Béthoux, J.-P.: Budgets of the Mediterranean Sea, Their dependence on the local climate and on characteristics of the Atlantic waters, Oceanologica Acta, 2, 157-153, 1979.

Béthoux, J.-P., Prieur, L., and Bong, J. H.: Le courant Ligure au large de Nice, Oceanologica Acta, 9, 59-67, 1988.

Bignami, F., Marullo, S., Santoleri, R., and Schiano, M. E.: Longwave radiation budget in the Mediterranean Sea, J. Geophys. Res., 100, 2501-2514, 1995.

Blanke, B. and Delecluse, P.: Variability of the tropical Atlantic ocean simulated by a general circulation model with two different mixed layer physics, J. Phys. Ocean., 23, 1363-1388, 1993.

Brasseur, P., Beckers, J.-M., Brankart, J.-M., and Schoenauen, R.: Seasonal temperature and salinity fields in the Mediterranean Sea: Climatological analysis of an historical data set, Deep Sea Res., 43, 2, 159-192, 1996.

Castellari, S., Pinardi, N., and Leaman, K.: Simulation of water mass formation processes in the Mediterranean Sea: Influence of the time frequency of the atmospheric forcing, J. Geophys. Res., 105, 24 157-24 181, 2000.

Conan, P. and Millot, C.: Variability of the Northern current off Marseilles, Western Mediterranean Sea, from February to June 1992, Oceanologica Acta, 18, 2, 193-205, 1995.

Crépon, M., Wald, L., and Monget, J. M.: Low-frequency waves in the Ligurian Sea during December 1977, J. Geophys. Res., 87, C1, 595-600, 1982.

Deleville, S.: Contribution à la modélisation de la dynamique marine d'été du Golfe du Lion, Application d'un modèle emboîté passif. Thèse de doctorat de l'université Aix-Marseille II, p. 170, 1997.

Demirov, E. and Pinardi, N.: Simulation of the Mediterranean Sea circulation from 1979 to 1993: Part I. The interannual variability, J. Marine Systems, in press, 2002.

Echevin, V.: Variabilité du niveau de la mer mesuré par altimétrie dans le golfe du Lion, Etude de l'influence de diverses observations sur la prévision de la circulation côtière, Thèse de l'Université Paul Sabatier, Toulouse, France, p. 191, 1998.

Estournel, C., Durrieu de Madron, X., Marsaleix, P., Auclair, F., Julliand, C., and Véhil, R.: Observation and modelisation of the winter coastal circulation in the Gulf of Lions under wind conditions influenced by continental orography (FETCH experiment), J. Geophys. Res., submitted, 2001.

Flexas, M., Garcia, M. A., Durrieu de Madron, X., Canals, M., and Arnau, P.: Flow variability in the Gulf of Lions during the MATER HFF experiment (March-May 1997), J. Marine Sys- 
tems, 33/34, 197-214, 2002.

Font, J., Garcia-Ladona, E., and Gorritz, E.: The seasonality of mesoscale motion in the Northern Current of the western Mediterranean Sea, Oceanologica Acta, 9, 51-57, 1995.

Fuda, J. L., Millot, C., Taupier-Letage, I., Send, U., and Bocognano, J. M.: XBT monitoring of a meridian section across the western Mediterranean Sea, Deep Sea Res. I, 47, 2191-2218, 2000.

Gasparini, G. P., Zodiatis, G., Astraldi, M., Calli, C., and Sparnocchia, S.: Winter intermediate water lenses in the Ligurian Sea, J. Marine Systems, 20, 319-332, 1999.

Griffiths, C., Ikeda, M., and Smith, P. C.: A numerical model comparison of baroclinic instability in the presence of topography, Tellus, 52A, 1, 42-65, 2000.

Herbaut, C., Mortier, L., and Crépon, M.: A sensitivity study of the general circulation of the western Mediterranean Sea, Part I: the response to density forcing through the straits, J. Phys. Ocean., 26, 65-84, 1996.

Herbaut, C., Martel, F., and Crépon, M.: A sensitivity study of the general circulation of the western Mediterranean Sea, Part II: the response to atmospheric forcing, J. Phys. Ocean., 27, 2126-2144, 1997.

Kondo, J.: Air-sea bulk transfer coefficients in adiabatic conditions, Boundary Layer Meteorology, 9, 91-112, 1975.

Korres, G.: A one-way nested eddy resolving model of the Aegean and Levantine basins: implementation and climatological runs, Ann. Geophysicae, 20, 1-16, 2002.

Korres, G., Pinardi, N., and Lascaratos, A.: The ocean response to low-frequency interannual atmospheric variability in the Mediterranean Sea. Part I: sensitivity experiments and energy analysis, J. Climate, 13, 705-731, 2000.

Legates, D. R.: A climatology of global precipitation, Publications in Climatology, 40, p. 84, 1987.

Macdonald, A. J. C. and Bryden, H. L.: An estimate of the net heat transport through the Strait of Gibraltar, in: Seasonal and interannual variability of the Western Mediterranean Sea, Coastal Estuarine Stud., 46, 249-285, AGU, Washington, D.C., 1994.

Madec, G., Chartier, M., and Crépon, M.: The effect of thermohaline forcing variability on deep water formation in the western Mediterranean Sea: a high-resolution three-dimensional numerical study, Dynamics of the Atmosphere and Oceans, 301-332, 1991.

Madec, G., Delecluse, P., Imbard, M., and Lévy, C.: OPA8.1 ocean general circulation model reference manual, Institut Pierre Simon Laplace, notes du pôle modélisation $\mathrm{n}^{\circ} 11$, p. 92, 1998.

Millot, C.: Wind-induced upwellings in the Gulf of Lions, Oceanologica Acta, 2, 3, 261-274, 1979.

Millot, C.: Circulation in the western Mediterranean Sea, Oceanologica Acta, 10, 2, 143-149, 1987.

Millot, C.: The Gulf of Lions hydrodynamics, Continental Shelf Research, 10, 9/11, 885-894, 1990.

Millot, C.: Mesoscale and seasonal variabilities of the circulation in the western Mediterranean Sea, Dynamics of the Atmosphere and Oceans, 15, 179-214, 1991.

Millot, C.: Circulation in the western Mediterranean Sea, J. Marine Systems, 20, 423-442, 1999.

Orlanski, I.: A simple boundary condition for unbounded hyperbolic flows, J. Computational Physics, 21, 251-269,1976.

Pichevin, T. and Nof, D.: The eddy canon, Deep-Sea Res., 43, 9, $1475-1507,1996$

Pinardi, N., Demirov, E., and Tonani, M.: Mediterranean Forecasting System Pilot Project: the initial forecasting phase. EuroGOOS Space Panel: Font, J., Gaspar, P., Guymer, T. H., Johannessen, J., van der Kolff, G. H., Le Provost, C., Ratier, A., Williams, D., and Flemming, N. C.: EuroGOOS conference on operational ocean observations from space, EuroGOOS publication $\mathrm{n}^{\circ} 16$, Southampton Oceanography Centre, Southampton. ISBN 0-904175-44-8, 2001a.

Pinardi, N., Auclair, F., Cesarini, C., Demirov, E., Fonda-Umani, S., Giani, M., Montanari, G., Oddo, P., Tonani, M., and Zavatarelli, M.: Toward marine environmental predictions in the Mediterranean Sea coastal areas: monitoring approach, in: Ocean Forecasting, (Eds) Pinardi, N. and Woods, J., Springer Berlin Heidelberg, New York, in press, 2001b.

Pinot, J.-M. and Ganachaud, A.: The role of winter intermediate waters in the spring summer circulation of the Balearic sea 1. Hydrography and inverse box modelling, J. Geophys. Res., 104(C12), 29 843-29 864, 1999.

Pinot, J.-M., Lopez-Jurado, J. L., and Riera, M.: The CANALES experiment (1996-1998). Interannual, seasonal, and mesoscale variability of the circulation in the Balearic channels, Progress in Oceanography, in press, 2002.

Sadoux, S., Baey, J.-M., Fincham, A., and Reynouard, D.: Experimental study of an intermediate current and its interaction with a cape, Dynamics of the Atmosphere and Oceans, 31, 165-192, 2000.

Salat, J., Sabates, A., Latasa, M., Vidal, M., Diez, B., Olivar, M. P., Emelianov, M., Marrase, C., Roldan, C., Moli, B., Castellon, A., and Balague, V.: A multidisciplinary Lagrangian survey of the spreading of surface low-salinity waters along the Catalan current in June 2000, Preliminary Results, 2000 LAPCOD Meeting, Ischia, Italy, October 2-6, 2000.

Stevens, I. G. and Johnson, J. A.: Sensitivity to open boundary forcing in a fine-resolution model of the Iberian shelf-slope region, Ann. Geophysicae, 15, 113-123, 1997.

Tang, C. M.: Baroclinic instability of stratified shear flows in the ocean and atmosphere, J. Geophys. Res., 80(9), 1168-1175, 1975.

Taupier-Letage, I. and Millot, C.: General hydrodynamical features in the Ligurian Sea inferred from the DYOME experiment, Oceanologica Acta, 9, 2, 119-131, 1986.

Wald, L.: Apport de la télédétection spatiale en infrarouge proche et moyen à la connaissance du milieu marin, Thèse de doctorat d'état, Université Toulon-Var, 1985. 